\title{
Cell Biology and Pathophysiology of $\alpha$-Synuclein
}

\author{
Jacqueline Burré, ${ }^{1}$ Manu Sharma, ${ }^{1}$ and Thomas C. Südhof ${ }^{2,3}$ \\ ${ }^{1}$ Appel Institute for Alzheimer's Disease Research, Brain and Mind Research Institute, Weill Cornell Medicine, \\ New York, New York 10021 \\ ${ }^{2}$ Departments of Molecular and Cellular Physiology, Stanford University Medical School, Stanford, \\ California 94305 \\ ${ }^{3}$ Howard Hughes Medical Institute, Stanford University Medical School, Stanford, California 94305 \\ Correspondence: jab2058@med.cornell.edu; mas2189@med.cornell.edu
}

$\alpha$-Synuclein is an abundant neuronal protein that is highly enriched in presynaptic nerve terminals. Genetics and neuropathology studies link $\alpha$-synuclein to Parkinson's disease (PD) and other neurodegenerative disorders. Accumulation of misfolded oligomers and larger aggregates of $\alpha$-synuclein defines multiple neurodegenerative diseases called synucleinopathies, but the mechanisms by which $\alpha$-synuclein acts in neurodegeneration are unknown. Moreover, the normal cellular function of $\alpha$-synuclein remains debated. In this perspective, we review the structural characteristics of $\alpha$-synuclein, its developmental expression pattern, its cellular and subcellular localization, and its function in neurons. We also discuss recent progress on secretion of $\alpha$-synuclein, which may contribute to its interneuronal spread in a prion-like fashion, and describe the neurotoxic effects of $\alpha$-synuclein that are thought to be responsible for its role in neurodegeneration.

$\boldsymbol{\alpha}$-Synuclein was identified in the electric organ of Torpedo californica using an antibody to purified cholinergic vesicles (Fig. 1) (Maroteaux et al. 1988). In addition to describing a presynaptic localization, Maroteaux et al. (1988) also detected $\alpha$-synuclein on the nuclear envelope, hence the name synuclein from synaptic vesicles ("syn") and the nuclear envelope ("nuclein"). Note, however, that the nuclear localization has not been observed in most subsequent studies and was likely caused by an antibody contaminant. A fragment of $\alpha$-synuclein comprising residues 61-95 was subsequently identified in senile plaques in Alzheimer's disease brains and was termed the non- $A \beta$-amy- loid component (NAC) (Ueda et al. 1993). In parallel, $\alpha$-synuclein mRNA was found to change specifically during song acquisition in zebra finches and was named "synelfin" because its identity with $\alpha$-synuclein was not realized (George et al. 1995). $\beta$-Synuclein, the second member of the synuclein family, was identified in rat and bovine brain, where it was also localized to presynaptic nerve terminals (Nakajo et al. 1990; Tobe et al. 1992). In initial studies, $\beta$-synuclein was also named phosphoneuroprotein 14 (Jakes et al. 1994; Nakajo et al. 1993). The third member of the synuclein family, $\gamma$ synuclein, was originally identified as BCSGC1 in metastatic breast cancer (Ji et al. 1997) and

Editor: Stanley B. Prusiner

Additional Perspectives on Prion Diseases available at www.perspectivesinmedicine.org

Copyright (C) 2018 Cold Spring Harbor Laboratory Press; all rights reserved; doi: 10.1101/cshperspect.a024091

Cite this article as Cold Spring Harb Perspect Med 2018;8:a024091 
J. Burré et al.
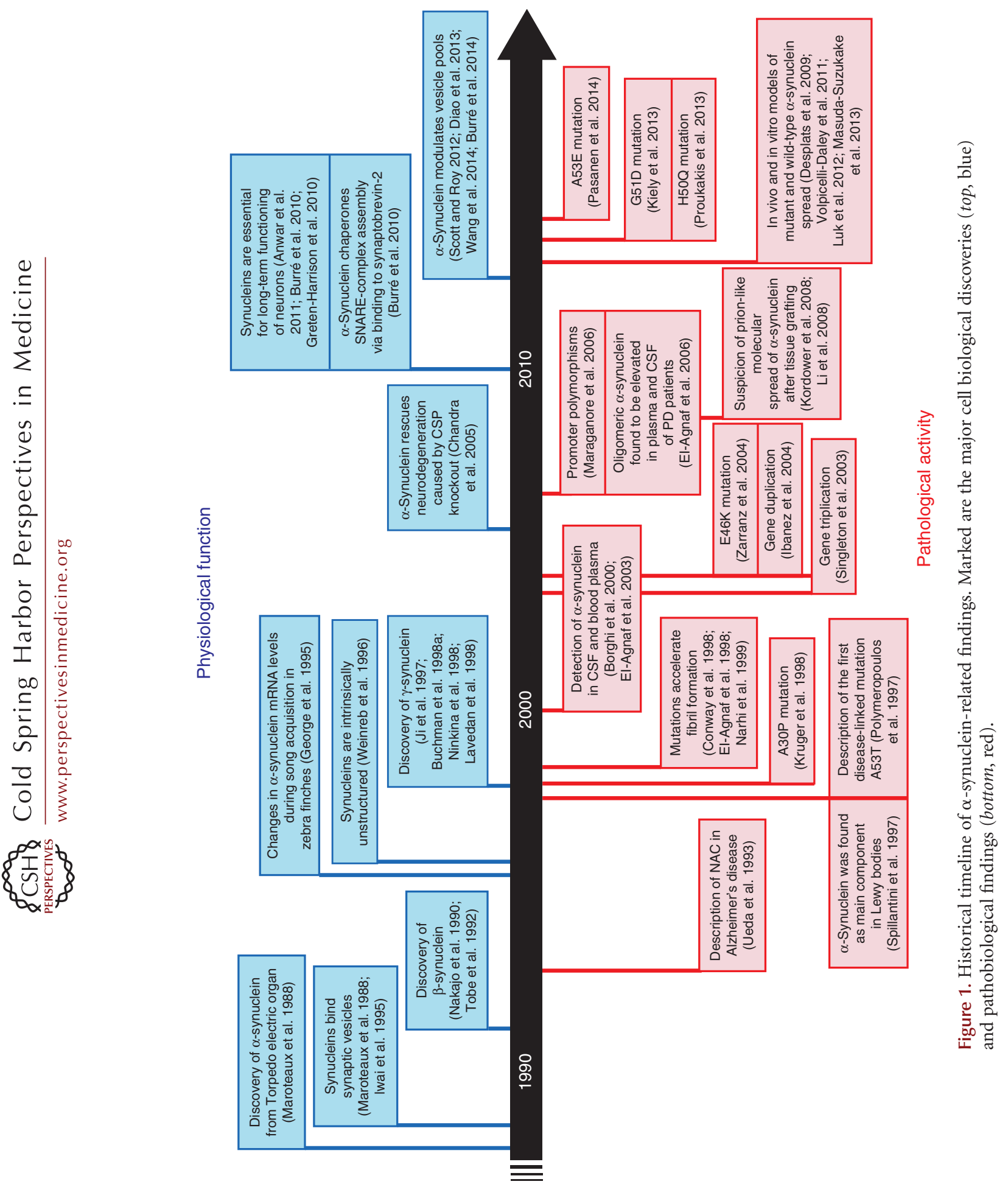
was subsequently cloned both as persyn (Buchman et al. 1998a; Ninkina et al. 1998) and $\gamma$ synuclein (Lavedan et al. 1998a).

$\alpha$-Synuclein became the focus of intense investigation when its central role in neurodegenerative diseases was realized (Polymeropoulos et al. 1997). $\alpha$-Synuclein is now known to be involved in Parkinson's disease (PD), dementia with Lewy bodies (which contain $\alpha$-synuclein aggregates as a major component), multiple system atrophy, neurodegeneration with brain iron accumulation type I, diffuse Lewy body disease, and Lewy body variant of Alzheimer's disease (Spillantini et al. 1997; Wakabayashi et al. 1997; Arawaka et al. 1998; Gai et al. 1998; see also Woerman et al. 2017). Lewy bodies containing $\alpha$-synuclein are a neuropathological hallmark of $\mathrm{PD}$, and missense mutations in $\alpha$-synuclein (A30P, E46K, H50Q, G51D, A53E, A53T [Polymeropoulos et al. 1997; Kruger et al. 1998; Zarranz et al. 2004; Kiely et al. 2013; Proukakis et al. 2013; Pasanen et al. 2014]), as well as $\alpha$-synuclein gene duplications and triplications (Singleton et al. 2003; Ibanez et al. 2004; Ferese et al. 2015), appear to cause PD. Moreover, polymorphisms in regulatory elements of the $\alpha$-synuclein gene predispose individuals to $\mathrm{PD}$ and are linked to an early onset of the disease (Maraganore et al. 2006). Yet, despite decades of intense studies, the cell biology of $\alpha$-synuclein remains largely unclear, and its specific neurodegenerative effect is poorly understood.

\section{$\alpha$-SYNUCLEIN STRUCTURE}

$\alpha-, \beta-$, and $\gamma$-synucleins are small soluble proteins (140, 134, and 127 amino acids, respectively) that bind to phospholipid membranes (Clayton and George 1998). The three synucleins contain a characteristic 11-residue sequence (consensus XKTKEGVXXXX), which is repeated seven times in $\alpha$ - and $\gamma$-synuclein, and six times in $\beta$-synuclein. This 11 -residue repeat forms an amphipathic $\alpha$-helix similar to apolipoproteins upon lipid binding (George et al. 1995). The NAC region is found within this repeated sequence. The NAC region of $\alpha$-synuclein is relatively hydrophobic and aggregationprone in human $\alpha$-synuclein but not in mouse $\alpha$-synuclein nor in the corresponding homologous region of human $\beta$-synuclein (Ueda et al. $1993)$. Yet, $\beta$-synuclein is more homologous to $\alpha$-synuclein in the $\mathrm{N}$-terminal sequences (74\%) than $\gamma$-synuclein $(67 \%)$. The acidic and glutamate-rich C-terminal sequence of synucleins is unstructured (Bertini et al. 2007; Wu et al. 2008) and was implicated in multiple protein interactions (Jensen et al. 1999; Giasson et al. 2003; Cherny et al. 2004; Fernandez et al. 2004): in ion, polycation, and polyamine binding (Paik et al. 1999; Nielsen et al. 2001; Hoyer et al. 2004; Brown 2007); in modulation of membrane binding of synucleins (Davidson et al. 1998; Jo et al. 2000; Perrin et al. 2000; Eliezer et al. 2001; Volles et al. 2001; Cole et al. 2002; Bussell and Eliezer 2003; Chandra et al. 2003; Fortin et al. 2004; Nuscher et al. 2004; Bussell et al. 2005); and in protection of $\alpha$-synuclein from aggregation (Crowther et al. 1998; Park et al. 2002, 2004; see also below). It is the substrate to multiple posttranslational modifications, some of which appear to be selectively enriched in $\alpha$-synuclein present in Lewy bodies (see discussion below).

All $\alpha$-synuclein missense mutations are localized within the membrane-binding domain of $\alpha$-synuclein containing the 11-residue repeats, although only three mutations affect lipid binding (Jo et al. 2002; Fares et al. 2014; Ghosh et al. 2014). Remarkably, the A53T substitution in human $\alpha$-synuclein that causes early-onset PD (Polymeropoulos et al. 1997) is normally present in mouse $\alpha$-synuclein, which has no tendency to aggregate, suggesting that the various PD-linked $\alpha$-synuclein point mutations produce a neurotoxic effect that is specific to the human $\alpha$-synuclein sequence context.

\section{$\alpha$-SYNUCLEIN CELLULAR POOLS}

$\alpha$-Synuclein exists in an equilibrium between a soluble and a membrane-bound state, with its secondary structure depending on its state (Fig. 2).

Soluble cytosolic $\alpha$-synuclein is intrinsically unstructured and behaves like a natively unfolded protein (Weinreb et al. 1996; Kim 1997; Chandra et al. 2003; Fauvet et al. 2012b; Burré et al. 2013). Recently, a soluble stable tetrameric 
J. Burré et al.

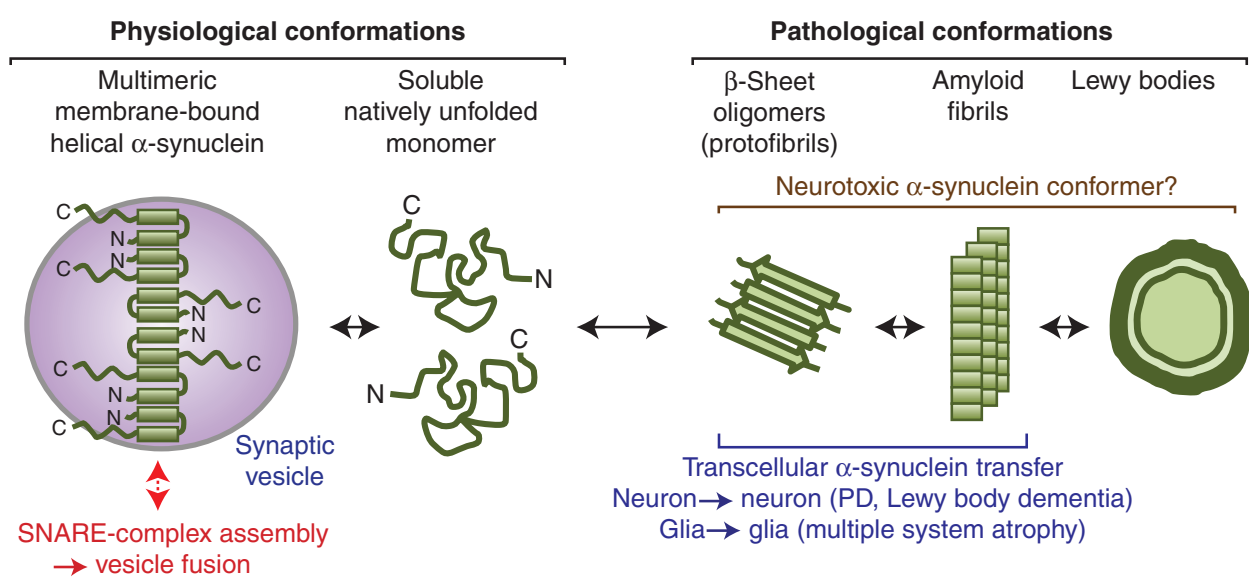

Figure 2. Schematic of $\alpha$-synuclein conformations associated with its physiological function and pathological activities. Soluble $\alpha$-synuclein is natively unstructured and monomeric. After binding to highly curved membranes, such as synaptic vesicles, $\alpha$-synuclein undergoes a conformational change and folds into an amphipathic $\alpha$-helix, which is associated with multimerization and mediates its SNARE-complex chaperoning function. Under pathological conditions, soluble $\alpha$-synuclein forms $\beta$-sheet-like oligomers (protofibrils), which convert into amyloid fibrils and eventually deposit into Lewy bodies. Protofibrils and fibrils may propagate from neuron to neuron in Parkinson's disease and Lewy body dementia and from glia to glia in multiple system atrophy. (From Burré et al. 2015; reprinted, with permission, from the authors.)

form of $\alpha$-synuclein has been described in human erythrocytes as defined by analytical centrifugation but was not clearly detectable by electron microscopy (Bartels et al. 2011; Wang et al. 2011) and was not found in other preparations (Binolfi et al. 2012; Fauvet et al. 2012b; Burré et al. 2013) or by using in vivo nuclear magnetic resonance (NMR) (Fig. 3) (Theillet et al. 2016).

$\alpha$-Synuclein binds to lipid membranes, such as artificial liposomes, lipid droplets, and lipid rafts. Upon lipid binding, the seven 11-residue repeat sequences of $\alpha$-synuclein adopt an $\alpha$-helical structure (Davidson et al. 1998; Jo et al. 2000; Perrin et al. 2000; Eliezer et al. 2001; Volles et al. 2001; Cole et al. 2002; Bussell and Eliezer 2003; Chandra et al. 2003; Fortin et al. 2004; Nuscher et al. 2004; Bussell et al. 2005). Membrane binding is likely a cooperative effect of the 11-mer sequences, as truncation of the $\mathrm{N}$-terminal domain reduces lipid binding drastically (Fig. 4). $\alpha$-Synuclein binding to lipid membranes requires acidic lipid head groups (Jo et al. 2000; Perrin et al. 2000; Middleton and Rhoades 2010), such as phosphatidylserine or phosphatidylinositol, suggesting an interaction of the membrane with lysines found on opposite sides of the $\alpha$-synuclein $\alpha$-helix. During lipid binding, $\alpha$-synuclein has been reported to adopt both a single elongated $\alpha$-helix and a broken $\alpha$ helix depending on the membrane curvature (Bussell and Eliezer 2003; Chandra et al. 2003; Bussell et al. 2005). Specifically, membranes with a larger diameter $(\sim 100 \mathrm{~nm})$ and lower curvature induce an elongated $\alpha$-helix in $\alpha$-synuclein (Bussell and Eliezer 2003; Jao et al. 2004, 2008; Georgieva et al. 2008; Trexler and Rhoades 2009). In contrast, in the presence of small highly curved vesicles, $\alpha$-synuclein adopts a broken $\alpha$-helix conformation (Chandra et al. 2003; Ulmer et al. 2005; Borbat et al. 2006; Drescher et al. 2008; Trexler and Rhoades 2009), likely to adapt to the smaller liposome area. $\alpha$-Synuclein preferentially binds to vesicles of smaller diameter (Davidson et al. 1998) and therefore associates with $\sim 40$-nm synaptic vesicles in the brain (Maroteaux et al. 1988; Iwai et al. 1995; Kahle et al. 2000). Recently, $\alpha$-synuclein was shown to oligomerize into multimers upon binding to membranes (Burré et al. 2014; Wang et al. 2014; see below).

In contrast to its physiological conformations outlined above, $\alpha$-synuclein adopts a $\beta$ - 
A

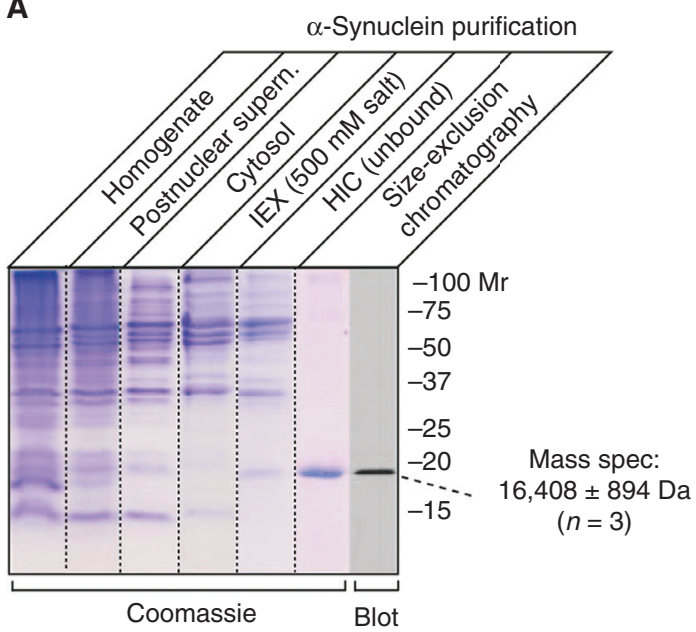

B

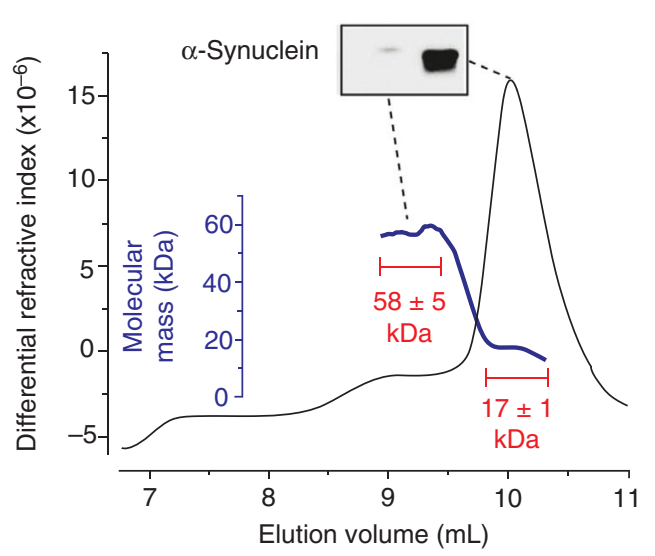

C

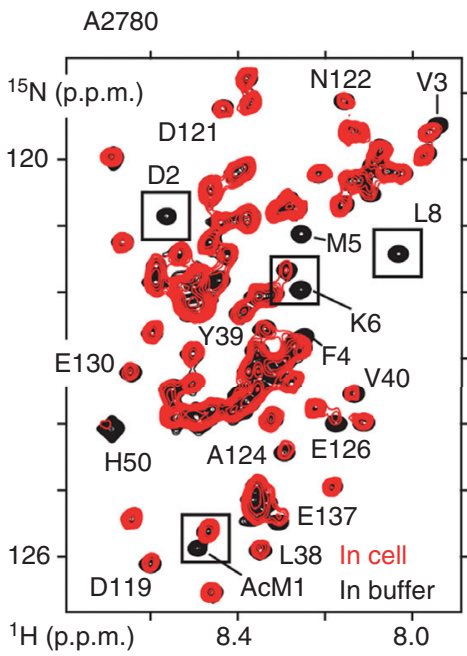

SK-N-SH

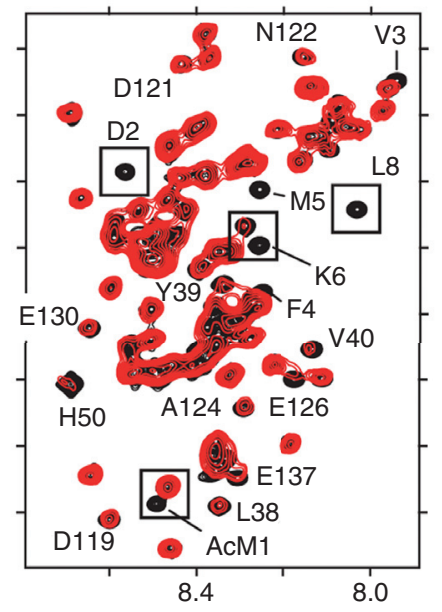

D

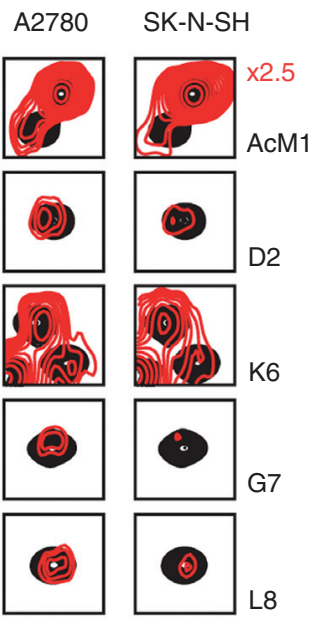

Figure 3. Soluble native $\alpha$-synuclein is predominantly an unstructured monomer. (A) Sodium dodecyl sulfate polyacrylamide gel electrophoresis (SDS-PAGE) analysis of five stages of $\alpha$-synuclein purification from mouse brain. Purified $\alpha$-synuclein was analyzed by immunoblotting and mass spectrometry as shown. (B) Sizeexclusion chromatography multi-angle light scattering (SEC-MALS) shows that purified $\alpha$-synuclein from mouse brain tissue is largely monomeric (main peak with a mass of $17 \pm 1 \mathrm{kDa}$ ), but includes a minor component (plateau along the left shoulder with a mass of $58 \pm 5 \mathrm{kDa}$ ) that contains little detectable $\alpha$ synuclein (see immunoblot in boxed region). Calculated masses were extracted from marked areas. (From Burré et al. 2013; reprinted, with permission, from the authors.) (C) Two-dimensional ${ }^{1} \mathrm{H}-{ }^{15} \mathrm{~N}$ nuclear magnetic resonance (NMR) spectra of $\alpha$-synuclein in A2780 and SK-N-SH cells (red, selected regions) and of isolated $\mathrm{N}$ terminally acetylated $\alpha$-synuclein in buffer (black). (D) N-terminal $\alpha$-synuclein residues experiencing siteselective signal attenuations (boxed) are expanded, with in-cell NMR contours plotted at 2.5-fold lower levels (red). In-cell NMR cross-peaks are superimposed with reference NMR signals of $\mathrm{N}$-terminally acetylated $\alpha$ synuclein in buffer (black), confirming the presence of this modification in mammalian cells. IEX, Anion exchange chromatography; HIC, hydrophobic interaction chromatography; AcM1, acetylated Met1. (From Theillet et al. 2016; reprinted, with permission, from Nature Publishing Group (C) 2016.) 
J. Burré et al.

A

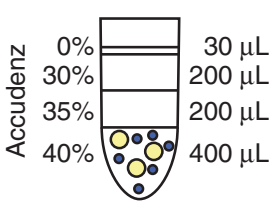

C

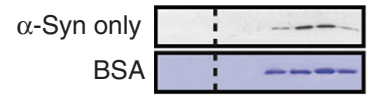

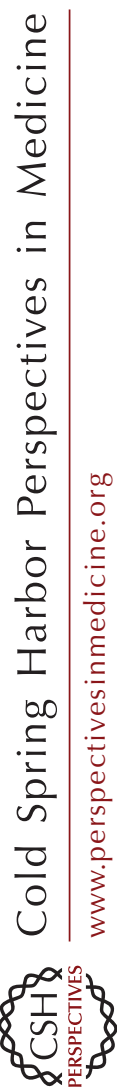

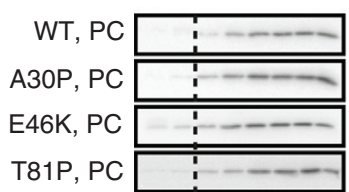

E

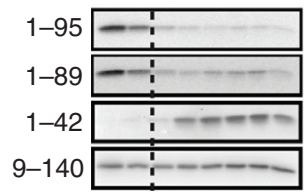

- Protein O Liposomes $\underset{3 \mathrm{hT}}{280.000 \mathrm{~g}}$ 3 h RT

\section{D}

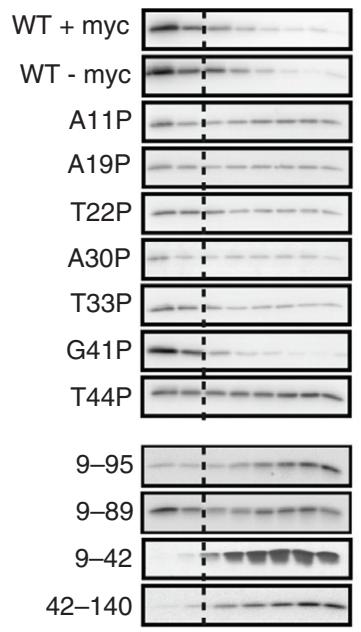

B

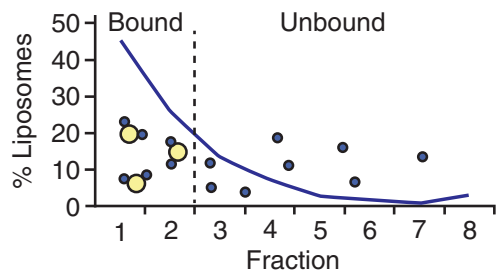

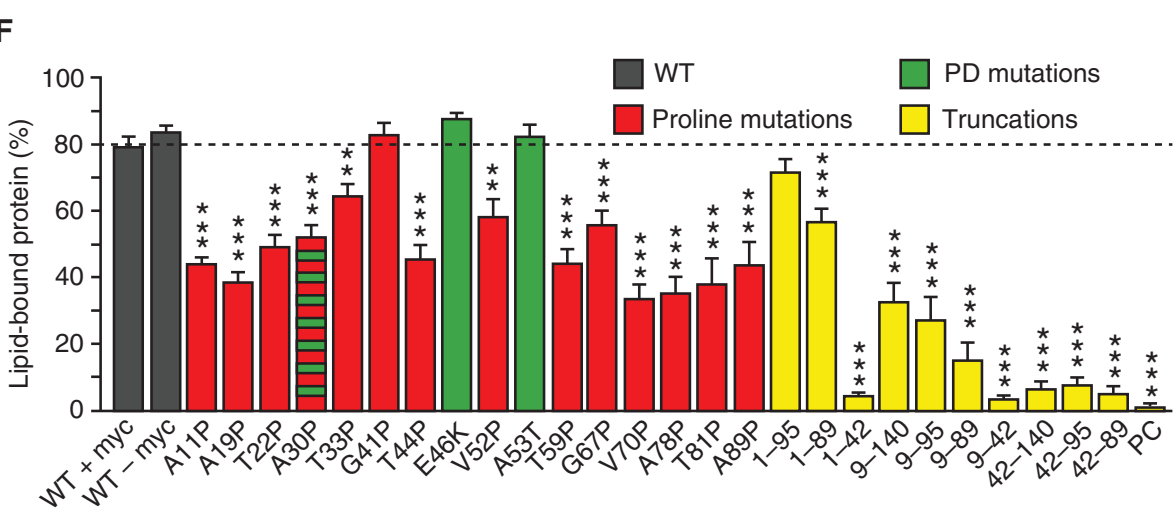

Figure 4. Binding of $\alpha$-synuclein mutants to phospholipid membranes. $(A, B)$ Phospholipid binding assay. Liposomes mixed with wild-type (WT) and mutant $\alpha$-synuclein were floated by density gradient centrifugation $(A)$. Based on liposome distribution in the gradient $(B)$, the top two fractions 1 and 2 were defined as lipidbound fractions. $(C)$ Lack of flotation of bovine serum albumin (BSA) and $\alpha$-synuclein in the absence of liposomes or with uncharged liposomes, analyzed by Coomassie staining or by immunoblotting with antibodies to the myc-epitope fused to $\alpha$-synuclein. $(D-F)$ Quantitation of phospholipid binding by WT and mutant $\alpha$ synuclein. Flotation of $\alpha$-synuclein point mutants $(D)$ and truncations $(E)$ with liposomes was quantitated as the sum of the top two fractions, and was plotted as the percentage of total $\alpha$-synuclein in the gradient $(F)$. Data are means \pm SEM $\left({ }^{* *} P<0.01,{ }^{* *} P<0.001\right.$ by Student's $t$-test; $n=6$ independent experiments $)$. RT, Room temperature. (From Burré et al. 2012; reprinted, with permission, from the authors.) 
sheet amyloid conformation under pathological conditions. This $\beta$-sheet conformation is associated with $\alpha$-synuclein aggregation, fibril formation, and deposition into Lewy bodies (Conway et al. 1998, 2000; El-Agnaf et al. 1998; Narhi et al. 1999; Rochet et al. 2000; Ding et al. 2002; Lashuel et al. 2002; Greenbaum et al. 2005; Fredenburg et al. 2007; Uversky 2007; Yonetani et al. 2009). The $\beta$-sheet conformation is thought to be neurotoxic, but the exact nature of the neurotoxic species remains unknown (Fig. 2).

\section{$\alpha$-SYNUCLEIN POSTTRANSLATIONAL MODIFICATIONS}

$\alpha$-Synuclein is subject to multiple posttranslational modifications, mostly within its carboxyterminal tail, including phosphorylation, oxidation, acetylation, ubiquitination, glycation, glycosylation, nitration, and proteolysis, resulting in changes in protein charge and structure, and leading to alterations in binding affinities with other proteins and lipids and overall protein hydrophobicity.

\section{Phosphorylation}

Phosphorylation of $\alpha$-synuclein may regulate its structure, membrane binding, oligomerization, fibril formation, and neurotoxicity (Fujiwara et al. 2002; Anderson et al. 2006). $\alpha$-Synuclein is constitutively phosphorylated, with serine 87 and serine 129 being major phosphorylation sites (Okochi et al. 2000; Pronin et al. 2000; Fujiwara et al. 2002; Kahle et al. 2002; Takahashi et al. 2003a; Chen and Feany 2005; Anderson et al. 2006; Kim et al. 2006; Ishii et al. 2007; Paleologou et al. 2010); repeated cycles of phosphorylation and dephosphorylation occur in vivo. Phosphorylation at S129 and S87 has been shown to inhibit aggregation of $\alpha$-synuclein (Waxman and Giasson 2008; Paleologou et al. 2010). Similarly, tyrosine phosphorylation at Y125, Y133, and Y135 is associated with suppression of $\alpha$-synuclein aggregation and toxicity (Ellis et al. 2001; Nakamura et al. 2001; Ahn et al. 2002; Negro et al. 2002; Takahashi et al. 2003b; Chen and Feany 2005; Chen et al. 2009).
In addition, phosphorylation of $\alpha$-synuclein at S129 and Y125 affects protein-protein interactions (McFarland et al. 2008). The exact kinases and phosphatases mediating $\alpha$-synuclein phosphorylation and dephosphorylation remain unknown. Yet, a variety of in vitro and cell-based studies have identified several kinases capable of phosphorylating $\alpha$-synuclein, including phosphorylation of $\alpha$-synuclein at $S 87$ by casein kinase I (Okochi et al. 2000) and Dyrk1A (Kim et al. 2006); at S129 by casein kinase I and II (Okochi et al. 2000), G-protein-coupled receptors 1, 2, 5, and 6 (Pronin et al. 2000), LRRK2 (Qing et al. 2009), and polo-like kinases (Inglis et al. 2009; Mbefo et al. 2010); at Y125 by Fyn (Nakamura et al. 2001), Syk (Negro et al. 2002), Lyn (Negro et al. 2002), c-Frg (Negro et al. 2002), and Src tyrosine kinases (Ellis et al. 2001); and at Y126 and Y133 by Syk tyrosine kinase (Negro et al. 2002).

\section{Acetylation}

Amino-terminal acetylation of $\alpha$-synuclein is seen both in healthy and PD individuals, and increases its helical folding propensity, its affinity for membranes, and its resistance to aggregation (Kang et al. 2012; Maltsev et al. 2012; Bartels et al. 2014; Dikiy and Eliezer 2014), mediated by attachment of an acetyl group to the $\alpha$-amino group of the first amino acid of $\alpha$-synuclein (Fauvet et al. 2012a; Kang et al. 2012; Maltsev et al. 2012; Burré et al. 2013).

\section{Sumoylation}

$\alpha$-Synuclein is primarily modified by SUMO1 via monosumoylation (Dorval and Fraser 2006). Sumoylation of $\alpha$-synuclein occurs at only one site, which is yet to be identified, at the N-terminus of the protein. The functional significance remains unknown and controversial: Sumoylation has been reported both to inhibit aggregation of $\alpha$-synuclein by promoting its solubility (Krumova et al. 2011; Shahpasandzadeh et al. 2014) and to promote aggregation (Kim et al. 2011; Oh et al. 2011). 
J. Burré et al.

\section{Ubiquitination}

The role of ubiquitination in modulating $\alpha$-synuclein aggregation remains poorly understood. $\alpha$-Synuclein colocalizes with ubiquitin in Lewy bodies (Mezey et al. 1998; Gomez-Tortosa et al. 2000), Lewy neurites (Gomez-Tortosa et al. 2000), and glial inclusions in multiple system atrophy (Gai et al. 1998). Four E3- and E4type ubiquitin ligases have been shown to ubiquitinate $\alpha$-synuclein: Parkin, ubiquitin carboxy-terminal hydrolase L1 (UCH-L1), C-terminus of Hsp70 interacting protein (CHIP), and SIAH (Liu et al. 2002; Liani et al. 2004; Lee et al. 2008; Rott et al. 2008; Tetzlaff et al. 2008). Parkin and UCH-L1 are linked to PD themselves (Leroy et al. 1998; Shimura et al. 2000), and Parkin and SIAH are present in Lewy bodies (Liani et al. 2004; Bandopadhyay et al. 2005). In vitro, $\alpha$-synuclein is ubiquitinated at K10, K21, K23, K32, K34, K43, and K96, with K21, K23, K32, and K34 being major sites (Nonaka et al. 2005; Rott et al. 2008). Studies in rat brain revealed major ubiquitination of K21 and K23 (Nonaka et al. 2005).

\section{Glycation}

Advanced glycation end products and $\alpha$-synuclein colocalize in the brains of PD patients (Munch et al. 2000), and glycation of $\alpha$-synuclein has been proposed to be a pathological hallmark of Lewy bodies (Munch et al. 2000; Shaikh and Nicholson 2008). Advanced glycation end products (Munch et al. 2000; Shaikh and Nicholson 2008), modification of $\alpha$-synuclein with dicarbonyl compounds glyoxal and methylglyoxal (Lee et al. 2009), and ribosylation of $\alpha$-synuclein (Chen et al. 2010) induce crosslinking of recombinant $\alpha$-synuclein in vitro, accelerating aggregation, and causing cytotoxicity (Munch et al. 2000; Shaikh and Nicholson 2008; Chen et al. 2010; Padmaraju et al. 2011).

\section{Glycosylation}

$\alpha$-Synuclein may be $O$-glycosylated in the brain at residues 53, 64, 72, and 87 (Wang et al. 2010; Alfaro et al. 2012). The biological and patholog- ical roles of $\alpha$-synuclein glycosylation remain unknown, although a recent report suggests that glycosylation of $\alpha$-synuclein in the NAC domain inhibits aggregation (Marotta et al. 2012).

\section{Nitration and Oxidation}

Nitration and oxidation have been implicated in the pathogenesis of PD and diffuse Lewy body disease. Yet, it is unclear whether they are a primary event leading to aggregation of $\alpha$-synuclein, or whether they occur upon reaction of reactive nitrogen species with preformed fibrils. $\alpha$-Synuclein contains four tyrosines, Y39, Y125, Y133, and Y136, with Y125 and Y39 being major nitration targets (Takahashi et al. 2002; Danielson et al. 2009). Nitration of $\alpha$-synuclein is believed to induce its oligomerization through cross-linking via oxidation of tyrosine to dityrosine, which may serve as a basis for the formation of larger $\alpha$-synuclein aggregates (Giasson et al. 2000). Yet, nitration inhibits fibril formation of $\alpha$-synuclein (Norris et al. 2003; Yamin et al. 2003; Hodara et al. 2004) and prevents fibrillation of nonmodified $\alpha$-synuclein (Yamin et al. 2003), suggesting a protective effect (Yamin et al. 2003). Nitration has also been reported to inhibit binding of $\alpha$-synuclein to lipid vesicles (Hodara et al. 2004; Sevcsik et al. 2011).

\section{Proteolysis}

C- and N-terminally truncated versions of $\alpha$ synuclein are present in the brains of healthy individuals and PD patients (Baba et al. 1998; Li et al. 2005; Liu et al. 2005a; Lewis et al. 2010; Muntane et al. 2012), suggesting that $\alpha$-synuclein truncation occurs under physiologically relevant conditions. Lewy bodies contain mostly full-length $\alpha$-synuclein, with the addition of small amounts of a C-terminally truncated species (Baba et al. 1998; Spillantini et al. 1998; Crowther et al. 1998; Campbell et al. 2001; Li et al. 2005; Liu et al. 2005a). C-terminal truncation of $\alpha$-synuclein increases its aggregation propensity (Rochet et al. 2000; Serpell et al. 2000; Murray et al. 2003; Hoyer et al. 2004; Li 
et al. 2005), because of the lack of charge balance between the C- and N-terminus (Bertoncini et al. 2005; Pawar et al. 2005), and could serve as the nucleus to seed aggregation of full-length $\alpha$-synuclein. Yet, the cleaving protease remains enigmatic. Neurosin (Ogawa et al. 2000; Iwata et al. 2003; Kasai et al. 2008) and calpain (Mishizen-Eberz et al. 2003; Dufty et al. 2007) are candidates because of their colocalization in Lewy bodies. In addition, cathepsin D (Takahashi et al. 2007; Sevlever et al. 2008), matrix metalloproteases (Sung et al. 2005; Levin et al. 2009), and ubiquitin-independent degradation of $\alpha$-synuclein by the proteasome (Tofaris et al. 2001) have been implicated in C-terminal proteolytic cleavage of $\alpha$-synuclein.

\section{Summary of $\alpha$-Synuclein Posttranslational Modifications}

The description above shows that $\alpha$-synuclein can be posttranslationally modified at many of its 140 residues and by a variety of cellular enzymes. Many of the above studies have used overexpression systems and have neglected the physiologically relevant localization of $\alpha$-synuclein, the synapse, when testing for the activity of kinases, phosphatases, or other enzymes. Thus, many of these modifications likely represent rare events. It is clear, however, that the structure of $\alpha$-synuclein, and thus its (dys-) function, can be heavily altered by posttranslational modifications. It remains to be determined which posttranslational modifications are physiologically relevant and which arise as a function of $\alpha$-synuclein-associated pathology.

\section{$\alpha$-SYNUCLEIN EXPRESSION AND LOCALIZATION}

$\alpha$ - and $\beta$-synucleins are expressed predominantly in the brain (Jakes et al. 1994), particularly in the neocortex, hippocampus, striatum, thalamus, and cerebellum (Nakajo et al. 1994; Iwai et al. 1995). Although $\gamma$-synuclein is detected in the brain (Buchman et al. 1998b), it is primarily expressed in the peripheral nervous system-in primary sensory, sympathetic, and motor neurons (Ji et al. 1997), as well as in the olfactory epithelium (Duda et al. 1999). It can also be expressed in ovarian tumors (Lavedan et al. 1998). $\gamma$-Synuclein, however, is also fairly robustly expressed in non-neuronal tissues and is increased in expression in some cancers (Ji et al. 1997; Jia et al. 1999; Liu et al. 2005b; Ahmad et al. 2007). Moreover, $\alpha$-synuclein, although highly enriched in the nervous system, is not limited to nervous tissues. $\alpha$-Synuclein has been detected in muscle, kidney, liver, lung, heart, testis, blood vessels, cerebrospinal fluid (CSF), blood plasma, platelets, lymphocytes, and red blood cells (Ueda et al. 1993; Jakes et al. 1994; Hashimoto et al. 1997; Askanas et al. 2000; Shin et al. 2000; Li et al. 2002; Tamo et al. 2002; Kim et al. 2004a; Ltic et al. 2004; Nakai et al. 2007). Thus, similar to proteins such as $N$-ethylmaleimide-sensitive factor (NSF) and synaptosomal-associated proteins (SNAP) (which function in ATP-dependent dissociation of soluble NSF attachment protein receptor [SNARE] complexes), synucleins are enriched in neurons but are ubiquitously expressed.

Within the nervous system, $\alpha$-synuclein is universally expressed throughout the brain (Lavedan 1998) in a developmentally regulated manner. In rodents, $\alpha$-synuclein mRNA expression begins in late embryonic stages, reaches a peak in the first few postnatal weeks, and then declines gradually (Kholodilov et al. 1999; Petersen et al. 1999). $\alpha$-Synuclein protein levels generally mirror mRNA levels, but remain high during adulthood (Petersen et al. 1999). $\alpha$-Synuclein levels in adults can be altered by various stimuli such as the herbicide paraquat (Manning-Bog et al. 2002), developmental injury to the brain (Kholodilov et al. 1999), neurotoxin MPTP (1-methyl-4-phenyl-1,2,3,6-tetrahydropyridine) (Vila et al. 2000), growth factors such as nerve growth factor and basic fibroblast growth factor (Clough and Stefanis 2007), and dopamine (Gomez-Santos et al. 2003, 2005). Overall, little is known about the characteristics and mechanisms of $\alpha$-synuclein expression, a subject that is of potential translational importance, given the role $\alpha$-synuclein levels play in PD predisposition. 
J. Burré et al.
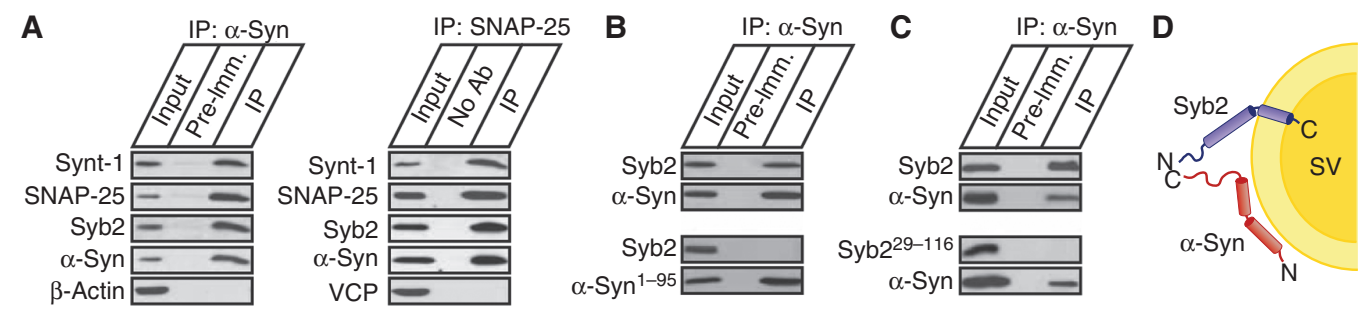

Figure 5. $\alpha$-Synuclein directly binds to synaptobrevin-2/vesicle-associated membrane protein 2 (VAMP2) in SNARE complexes. (A) Coimmunoprecipitation of $\alpha$-synuclein with SNARE complexes reconstituted in HEK293T cells. Cell lysates were immunoprecipitated with antibodies to (left) $\alpha$-synuclein or (right) SNAP25 and analyzed by means of immunoblotting. $(B, C)$ The $\mathrm{C}$ terminus of $\alpha$-synuclein directly binds to the $\mathrm{N}$ terminus of synaptobrevin-2. $\alpha$-Synuclein was immunoprecipitated from HEK293T cells coexpressing fulllength $\left(\alpha\right.$-Syn) or C-terminally truncated $\alpha$-synuclein $\left(\alpha-S_{y n}{ }^{1-95}\right)$ with full-length (Syb2) or N-terminally truncated synaptobrevin-2 (Syb2 $\left.{ }^{29-116}\right)$. Immunoprecipitates were analyzed by means of immunoblotting of $\alpha$-synuclein and synaptobrevin-2. (D) Diagram of the $\alpha$-synuclein/synaptobrevin-2 complex on synaptic vesicles (SVs). (From Burré et al. 2010; reprinted, with permission, from the authors.)

\section{Localization to the Synapse}

During the development of cultured neurons, $\alpha$-synuclein is first localized to the soma of the immature neuron and then becomes concentrated in presynaptic terminals as synapses are being formed in murine (Withers et al. 1997; Hsu et al. 1998) and in humans (Bayer et al. 1999; Galvin et al. 2001). Interestingly, although $\alpha$-synuclein is one of the best markers for presynaptic terminals, it is among the last presynaptic proteins to become enriched in terminals (Withers et al. 1997), suggesting that it does not play a central function in synapse development. Targeting of $\alpha$-synuclein to the synapse may be mediated by its preference for synaptic vesicle membranes (Maroteaux et al. 1988; Jensen et al. 1999) and/or binding to the vesicular SNARE protein synaptobrevin-2 (Fig. 5) (Burré et al. 2010). In support of the latter hypothesis, knockout of synaptobrevin-2 decreases targeting of $\alpha$-synuclein to the synapse (Burré et al. 2012).

\section{Localization to Mitochondria}

Multiple studies reported that $\alpha$-synuclein localizes to and binds to mitochondria ( $\mathrm{Li}$ et al. 2007; Cole et al. 2008; Devi et al. 2008; Nakamura et al. 2008; Liu et al. 2009). Because mitochondria, different from synaptic vesicles, are not specific to nerve terminals, it is difficult to reconcile the presynaptic localization of $\alpha$-synuclein with a mitochondrial function. The potential function of $\alpha$-synuclein in mitochondria is unclear because both overexpression and loss of $\alpha$-synuclein was proposed to cause mitochondrial dysfunction (Ellis et al. 2005; Smith et al. 2005; Martin et al. 2006; Stichel et al. 2007). Overexpression of $\alpha$-synuclein in multiple cell types, including neurons, can lead to fragmentation of mitochondria (Kamp et al. 2010; Nakamura et al. 2011), not by preventing fusion, but by promoting mitochondrial fission (Nakamura et al. 2011). In vitro, membranes containing the mitochondrial phospholipid cardiolipin can be fragmented by oligomerized $\alpha$-synuclein (Nakamura et al. 2011). Interestingly, $\beta$ - and $\gamma$-synuclein can also affect mitochondrial morphology, although to a lesser extent than $\alpha$-synuclein (Nakamura et al. 2011), which suggests the involvement of the $\mathrm{N}$-terminal membrane-binding domain, which is highly conserved between the three synuclein isoforms. The A53T mutant version of $\alpha$-synuclein, when overexpressed in primary neurons, up-regulates autophagic engulfment of mitochondria (mitophagy) (Choubey et al. 2011), and mitochondrial degeneration was reported in transgenic mice overexpressing A53T $\alpha$-synuclein (Martin et al. 2006). 
On the molecular level, $\alpha$-synuclein overexpression appears to inhibit complex I (Li et al. 2007; Devi et al. 2008; Nakamura et al. 2008; Liu et al. 2009; Chinta et al. 2010; Loeb et al. 2010), which, in combination with the ability of $\alpha$ synuclein to disrupt mitochondrial membrane integrity, may lead to increased production of reactive oxygen species (ROS) (Hsu et al. 2000; Junn and Mouradian 2002; Winklhofer and Haass 2010). This pathogenic cascade of $\alpha$-synuclein may overlap with other mitochondrial/ ROS-related neuropathology that causes PD, such as PINK1, parkin, and LRRK mutations, or sporadic PD caused by mitochondrial toxins. The importance of mitochondrial dysfunction in synucleinopathies is further suggested by studies in which $\alpha$-synuclein-dependent mitochondrial dysfunction or ROS production were counteracted by molecular or pharmacological means, which led to neuroprotective effects in mammalian systems (Hsu et al. 2000; Clark et al. 2010; Liu et al. 2011) and in Drosophila (Wassef et al. 2007; Botella et al. 2008).

\section{Localization to the Nucleus, Endoplasmic Reticulum, and Golgi}

$\alpha$-Synuclein was named in part because of a presumed localization to the nucleus (Maroteaux et al. 1988). Since then, the reports of nuclear localization of $\alpha$-synuclein have not been consistent (Mori et al. 2002; Yu et al. 2007). Phosphorylation of $\alpha$-synuclein at S129 was proposed to increase its nuclear localization in transgenic mice overexpressing $\alpha$-synuclein with the A30P mutation (Schell et al. 2009). In the nucleus, $\alpha$-synuclein is reported to inhibit histone acetylation (Kontopoulos et al. 2006), and histone deacetylase (HDAC) inhibitors were able to rescue neurotoxicity caused by $\alpha$ synuclein in cell culture and in transgenic Drosophila (Kontopoulos et al. 2006). In agreement, inhibition or siRNA-mediated knockdown of Sirtuin-2, an HDAC, protected against $\alpha$-synuclein mediated dopaminergic neuron death in culture and transgenic Drosophila models ( $\mathrm{Ou}-$ teiro et al. 2007).

$\alpha$-Synuclein was also proposed to associate with the Golgi complex and various secretory and endosomal compartments other than synaptic vesicles. Endoplasmic reticulum (ER) associated stress was observed in a cell culture model of A53T $\alpha$-synuclein-induced cell death (Smith et al. 2005). Golgi fragmentation correlated with small, prefibrillar oligomers of $\alpha$-synuclein (Gosavi et al. 2002). Blockade of ER-Golgi traffic was found to be involved in $\alpha$-synuclein toxicity in yeast, and could be rescued by overexpression of rab1-a protein involved in ER-Golgi traffic (Cooper et al. 2006). Overexpression of $\alpha$-synuclein severely delayed ER-Golgi transport in non-neuronal cells by inhibiting ER/Golgi SNARE protein function (Thayanidhi et al. 2010). These rab and SNARE effects of $\alpha$-synuclein in non-neuronal cells may derive from its native function on the presynaptic membranes.

\section{Localization to the Cytoskeleton}

$\alpha$-Synuclein interacts with multiple cytoskeletal components in vitro. The helical membranebinding domain of $\alpha$-synuclein, when bound to lipids, associates with cellular proteins like tubulin (Alim et al. 2002; Zhou et al. 2010), kinesin light chain, dynein heavy chain, and septin-4 (Woods et al. 2007). However, the proposed effects of $\alpha$-synuclein on tubulin polymerization are unclear, with inhibition reported by some (Lee et al. 2006a; Zhou et al. 2010) and enhancement by others (Alim et al. 2002). Importantly, aggregates of the microtubule-associated protein tau have been implicated in certain cases of PD (Kotzbauer et al. 2004), and tau shows a high association with PD in genomewide association studies (Nalls et al. 2011). $\alpha$ Synuclein enhances phosphorylation of tau (Jensen et al. 1999; Haggerty et al. 2011; Qureshi and Paudel 2011), and tau and $\alpha$-synuclein can seed aggregation of each other (Giasson et al. 2003), possibly accelerating the neuropathological cascade.

\section{$\alpha$-Synuclein Expression and Localization Summary}

The description above shows that $\alpha$-synuclein is a ubiquitously expressed protein that is highly 
J. Burré et al.

enriched in neurons, in which $\alpha$-synuclein is largely concentrated in presynaptic terminals where it is localized to synaptic vesicles. In addition to these observations, a significant number of additional localizations have been proposed for $\alpha$-synuclein, as described above, largely based on overexpression studies. Many of these results likely represent rare events whose significance is unclear. For example, synaptic vesicles in presynaptic terminals are not in contact with microtubules, suggesting that the vast majority of $\alpha$-synuclein that is on synaptic vesicles cannot be bound to microtubules or tau. Similarly, mitochondria are not nearly as enriched in presynaptic terminals as synaptic vesicles or as endogenous $\alpha$-synuclein, arguing against a significant association between $\alpha$-synuclein and mitochondria. The same argument applies even more to the endoplasmic reticulum, which is not at all enriched in terminals, and to the nucleus and Golgi apparatus, which are absent from terminals. Thus, the very fact that endogenous $\alpha$-synuclein is normally enriched in presynaptic terminals provides good evidence against many of the localizations proposed for $\alpha$-synuclein other than synaptic vesicles.

\section{$\alpha$-Synuclein and Protein Degradation Mechanisms}

It is proposed that $\alpha$-synuclein is degraded by multiple mechanisms, from the ubiquitin proteasome pathway and autophagy-lysosome system to extracellular metalloproteases. Initial studies showed that proteasome inhibition led to accumulation of $\alpha$-synuclein (Bennett et al. 1999; McLean et al. 2001). Then the autophagy-lysosomal pathway was also implicated in $\alpha$-synuclein degradation (Webb et al. 2003; Cuervo et al. 2004; Lee et al. 2004), which was further narrowed down to chaperone-mediated autophagy (CMA) (Cuervo et al. 2004; Bandyopadhyay and Cuervo 2007).

The ability of $\alpha$-synuclein to block various degradation pathways, especially in its oligomeric/aggregate form, has garnered considerable research interest, which is possibly because of the attractive notion that this would create a vicious cycle leading to further accumulation of $\alpha$-synuclein oligomers/aggregates. Overexpression of mutant $\alpha$-synuclein in cell lines revealed inhibition of the ubiquitin-proteasome system (Stefanis et al. 2001; Tanaka et al. 2001), sensitization to proteasome inhibitors because of decreased proteasome activity (Petrucelli et al. 2002), or no effect on the proteasome (Martin-Clemente et al. 2004). Any effect on the proteasome may be direct, as interactions between monomeric and aggregated $\alpha$-synuclein and the proteasomal subunit $\mathrm{S}^{\prime}$ of the $19 \mathrm{~S}$ regulatory complex as well as subunits of the $20 \mathrm{~S}$ proteasome have been observed (Snyder et al. 2003; Lindersson et al. 2004). $\alpha$-Synuclein aggregates of various sizes, from soluble oligomers to filaments, were shown to inhibit proteasome activity (Lindersson et al. 2004; Emmanouilidou et al. 2010b).

Inhibition of CMA by $\alpha$-synuclein has also been widely reported, with decreased levels of CMA proteins LAMP2A and Hsc70 in PD brains (Alvarez-Erviti et al. 2010). Although wild-type (WT) $\alpha$-synuclein is translocated into lysosomes for degradation via CMA, A30P and A53T $\alpha$-synuclein mutants inhibit uptake (Cuervo et al. 2004), and inhibition of CMA by $\alpha$-synuclein causes a compensatory increase in macroautophagy (Xilouri et al. 2009). However, inhibition of macroautophagy by WT $\alpha$-synuclein has also been reported (Winslow et al. 2010).

\section{$\alpha$-SYNUCLEIN IN EXTRACELLULAR SPACE AND ITS PRION-LIKE SPREAD}

Because early symptoms of PD were highly stereotyped, $\alpha$-synuclein aggregates were thought to exert their pathogenic effect in a cell-autonomous and brain-area-specific manner. However, this model was first challenged by a pattern of anatomical progression of Lewy body pathology and neuron loss beginning in brainstem nuclei, extending to the midbrain, and finally to cortical areas (Braak et al. 2004), which may account for the symptomatic progression of $\mathrm{PD}$ beyond the most obvious initial motor symptoms, such as depression, autonomic and sensory dysfunction, and dementia. One of the 
earliest indications of extracellular $\alpha$-synuclein was its detection in the extracellular fluids such as CSF and blood plasma (Borghi et al. 2000; El-Agnaf et al. 2003). The amount of extracellular $\alpha$-synuclein, however, was not clearly correlated with PD, as elevation (Lee et al. 2006b), as well as reduction (Tokuda et al. 2010), of $\alpha$ synuclein was reported in blood samples from PD patients. Although oligomeric $\alpha$-synuclein is found at elevated levels in the plasma and CSF of PD patients (El-Agnaf et al. 2006), it remains uncertain whether $\alpha$-synuclein in bodily fluids is a useful indicator/biomarker of disease.

Suspicion of prion-like molecular spread of $\alpha$-synuclein came from postmortem studies of PD patients who had received fetal brain tissue grafts (Lindvall et al. 1994; Olanow et al. 2003). In patients who died 11-16 years after transplantation, the grafted neurons showed Lewy bodies that were essentially identical in content and character to those in the PD-afflicted brain (Kordower et al. 2008; Li et al. 2008; Kurowska et al. 2011). Likely, this neuron-to-neuron spread appears to be a prion-like propagation of $\alpha$-synuclein, with evidence accumulating from in vitro and in vivo models of not only mutant and WT $\alpha$-synuclein spread (Desplats et al. 2009; Luk et al. 2012; Masuda-Suzukake et al. 2013), but also from extraneuronal spread of A $\beta$ (Petkova et al. 2005; Jucker and Walker 2011) and tau (Clavaguera et al. 2009; Frost et al. 2009).

Release of $\alpha$-synuclein appears to be through unconventional exocytosis pathways. Although the molecular mechanisms are not well understood, a growing number of cytosolic proteins seem to be released into the extracellular space (Nickel 2003). Some evidence indicates that $\alpha$-synuclein may be released with exosomes-luminal vesicles of multivesicular bodies (MVBs), which are classically understood to be on their way to degradation in lysosomes (Emmanouilidou et al. 2010a). This release appears to be calcium-dependent (Lee et al. 2005; Paillusson et al. 2013), providing a neuronal activity-dependent mechanism for $\alpha$ synuclein exocytosis, and may suggest spread along synaptically connected neurons.
Once in the extracellular space, $\alpha$-synuclein may be removed by proteolysis by extracellular enzymes such as matrix metalloproteases (Sung et al. 2005) or via uptake by surrounding cells. Extracellular $\alpha$-synuclein can be endocytosed by neurons and microglia (Sung et al. 2001; Zhang et al. 2005), although non-endocytosisdependent uptake has also been reported (Ahn et al. 2006a). Fibrils of recombinant $\alpha$-synuclein can also be endocytosed by neurons and lead to aggregates of Lewy-body-like pathology in cells expressing endogenous levels of $\alpha$-synuclein (Volpicelli-Daley et al. 2011). Exocytosis and uptake of $\alpha$-synuclein may be an important mechanism for the progression and amplification of degenerative changes in synucleinopathies from a few cells to the surrounding tissue, or it may also have a biological function that is not yet known (see also Hasegawa et al. 2016; Tofaris et al. 2016).

\section{$\alpha-S Y N U C L E I N$ FUNCTION}

In addition to its well-validated binding to negatively charged phospholipids (Davidson et al. 1998; Bussell and Eliezer 2003; Chandra et al. 2003), $\alpha$-synuclein has been reported to interact with a variety of proteins and to perform a number of functions in conjunction with these protein interactions. These binding and functional activities include binding and inhibition of phospholipase D (Jenco et al. 1998; Ahn et al. 2002; Payton et al. 2004; Gorbatyuk et al. 2010); regulation of the interaction of the small GTP-binding protein rab3 with membranes, especially synaptic vesicles (Chen et al. 2013); binding to the SNARE-protein synaptobrevin-2 and chaperoning SNARE-complex assembly (Figs. 5 and 6) (Burré et al. 2010); binding to and regulation of tyrosine hydroxylase (TH) (Masliah et al. 2000; Kirik et al. 2002; Perez et al. 2002; Baptista et al. 2003; Yu et al. 2004); binding to DJ-1 (Zondler et al. 2014) and to synphilin (Engelender et al. 1999; McLean et al. 2001; Ribeiro et al. 2002); regulation of microtubules via binding to tubulin (Lee et al. 2006a); and enhancement of tau phosphorylation (Jensen et al. 1999; Haggerty et al. 2011; Qureshi and Paudel 2011). Yet, the 
J. Burré et al.

A

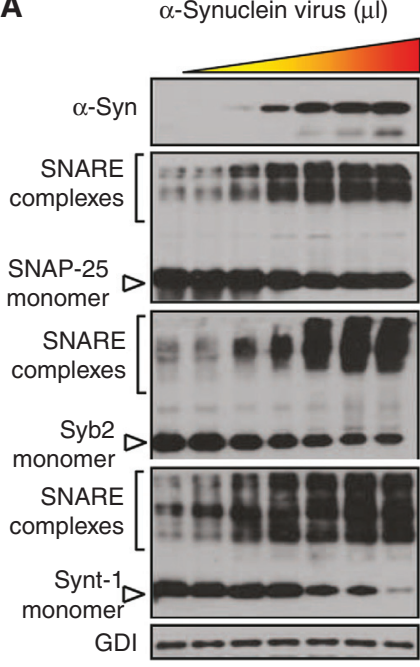

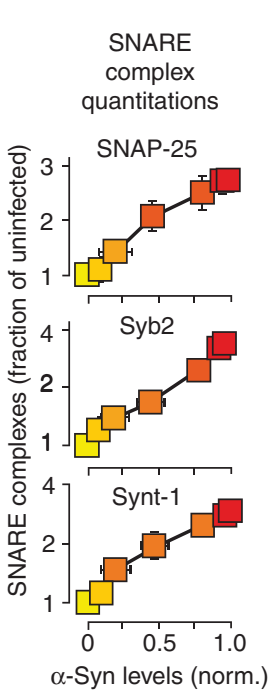

B
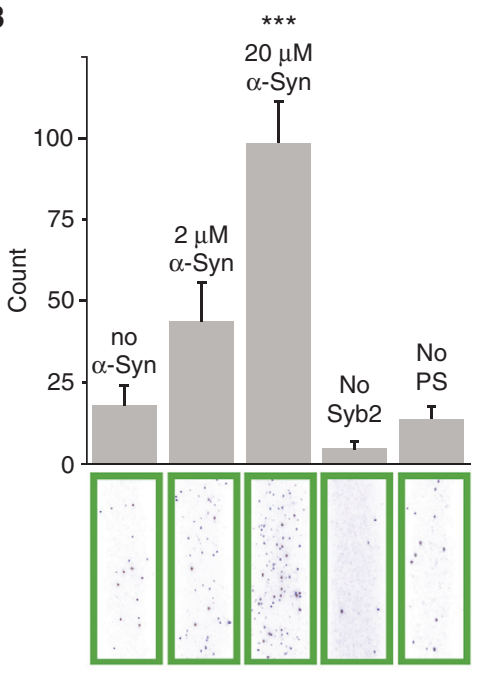

Figure 6. $\alpha$-Synuclein boosts SNARE-complex assembly and clusters liposomes. (A) Linear relationship between $\alpha$-synuclein levels and SNARE-complex assembly in $\alpha, \beta, \gamma$-synuclein triple-knockout neurons infected at DIV4 with increasing amounts of lentivirus expressing $\alpha$-synuclein and analyzed by means of immunoblotting of nonboiled samples at DIV17 ( $n=3$ to 6 cultures). (From Burré et al. 2010; reprinted, with permission, from the authors.) (B) Native $\alpha$-synuclein promotes liposome vesicle clustering in a concentration-dependent manner by binding to both synaptobrevin-2 and anionic membranes. Bar graph: Quantitation of interacting vesicles. (Bottom panel) Representative fluorescence images of interacting vesicles on the imaging surface. Data are means $\pm \mathrm{SD}\left({ }^{* * *} P<0.001\right.$ by Student's $t$-test; $n=15$ random imaging locations in the sample channel). (From Diao et al. 2013; reprinted, with permission, from the authors.)

physiological significance of most of these interactions remains unclear.

\section{Lipid Transport, Lipid Packing, and Membrane Biogenesis}

The binding of $\alpha$-synuclein to phospholipids and the similarity of $\alpha$-synuclein with class A2 apolipoproteins suggests a role in lipid transport. $\alpha$-Synuclein has been reported to bind to fatty acids (Sharon et al. 2001), and may thus serve as a fatty acid transporter between the cytosol and membrane compartments, although other studies suggest the contrary (Lucke et al. 2006). Furthermore, $\alpha$-synuclein has been shown to induce membrane curvature and convert large vesicles into highly curved membrane tubules and vesicles, as would be expected for a lipid-binding protein (Varkey et al. 2010; Westphal and Chandra 2013). In addition, $\alpha$-synuclein has been reported to be a specific inhibitor of phospholipases D1 and
D2 in vitro and in vivo (Jenco et al. 1998; Ahn et al. 2002; Payton et al. 2004; Gorbatyuk et al. 2010 ), suggesting that $\alpha$-synuclein may be involved in cleavage of membrane lipids and membrane biogenesis. Moreover, it has been suggested that $\alpha$-synuclein senses lipid-packing defects and affects lipid packing (Kamp and Beyer 2006; Ouberai et al. 2013), indicating that besides binding to membranes, $\alpha$-synuclein may be able to actively remodel them.

\section{Molecular Chaperone Activity}

The biochemical structure of $\alpha$-synuclein predicts a function as a molecular chaperone capable of binding to other intracellular proteins. This hypothesis was strengthened by three observations: First, $\alpha$-synuclein shares structural and functional homology with the 14-3-3 family of molecular chaperone proteins (Ostrerova et al. 1999). Second, via its C-terminal domain, $\alpha$-synuclein suppresses the aggregation of ther- 
mally denatured proteins (Kim et al. 2000, 2002, 2004b; Souza et al. 2000; Rekas et al. 2004; Ahn et al. 2006b), and overexpression of $\alpha$-synuclein protects dopaminergic neurons from oxidative stress and apoptosis (da Costa et al. 2000; Kanda et al. 2000). Third, $\alpha$-synuclein rescues the lethal neurodegeneration caused by knockout of the cochaperone CSP $\alpha$ in mice by chaperoning assembly of synaptic SNARE complexes (Chandra et al. 2005; Burré et al. 2010). This function of $\alpha$-synuclein is essential for long-term functioning of neurons, as $\alpha-, \beta-, \gamma$-synuclein tripleknockout mice have reduced SNARE-complex assembly, show neuropathological signs, and have shortened survival (Burré et al. 2010; Greten-Harrison et al. 2010; Anwar et al. 2011).

\section{Vesicle Trafficking}

A large body of evidence from studies in worm, yeast, fly, and mouse models shows that $\alpha$-synuclein is associated with defects in vesicle trafficking. In yeast, $\alpha$-synuclein inhibits ER-Golgi trafficking, which can be rescued by overexpression of the rab GTPase that functions in this trafficking step (Cooper et al. 2006), and causes accumulation of transport vesicles by inhibiting vesicle docking and/or fusion (Gitler and Shorter 2007). In mammalian cells, $\alpha$-synuclein perturbs ER-Golgi trafficking as well (Gosavi et al. 2002), and PD-causing mutations increase this effect (Thayanidhi et al. 2010). $\alpha$-Synuclein induces aggregation of rab proteins in yeast (Soper et al. 2011), triggering defects in endosomal trafficking. Mutant A30P $\alpha$-synuclein interacts with rab3a, rab5, and rab8, potentially compromising synaptic vesicle trafficking, endocytosis, and $\alpha$-synuclein transport (Dalfo et al. 2004). Additionally, abnormal binding of $\alpha$-synuclein to rab3a in multiple system atrophy was observed (Dalfo and Ferrer 2005).

\section{Dopamine Synthesis and Transport}

$\alpha$-Synuclein inhibits dopamine synthesis by inhibiting the expression and activity of TH (Masliah et al. 2000; Kirik et al. 2002; Perez et al. 2002; Baptista et al. 2003; Yu et al. 2004), likely by reducing the phosphorylation state of $\mathrm{TH}$ and stabilizing dephosphorylated inactive TH (Perez et al. 2002; Peng et al. 2005; Lou et al. 2010; $\mathrm{Wu}$ et al. 2011). In agreement, aging-related increases in $\alpha$-synuclein expression in the substantia nigra negatively correlate with the expression of TH (Chu and Kordower 2007). Moreover, $\alpha$-synuclein affects the dopaminetransporting vesicular transporter VMAT2: Knockdown of $\alpha$-synuclein increases the density of VMAT2 molecules per vesicle, whereas overexpression inhibits VMAT2 activity, interrupting dopamine homeostasis by causing increased cytosolic dopamine levels (Guo et al. 2008).

\section{Neurotransmitter Release and Synaptic Plasticity}

The presynaptic localization of $\alpha$-synuclein, its interaction with synaptic vesicles (Maroteaux et al. 1988; Perrin et al. 2000) and synaptobrevin-2 (Burré et al. 2010), its SNARE-complex chaperoning activity (Burré et al. 2010), and its changes during periods of song-acquisition-related synaptic rearrangement in birds (George et al. 1995) strongly suggests that $\alpha$-synuclein plays a role in neurotransmitter release and synaptic plasticity, although its precise function remains unclear. Yet, absence of $\alpha$-synuclein in worms, flies, and yeast suggests that $\alpha$-synuclein is not required for synaptic transmission or membrane trafficking in general. Knockout of $\alpha-, \alpha / \beta-, \alpha / \gamma^{-}$, or $\alpha / \beta / \gamma$-synucleins does not induce morphological changes in the brain (Abeliovich et al. 2000; Chandra et al. 2004; Burré et al. 2010; Anwar et al. 2011), although changes in synapse structure (Greten-Harrison et al. 2010) and an impairment in survival have been reported in triple-knockout mice (Burré et al. 2010; Greten-Harrison et al. 2010), suggesting that synucleins contribute to the longterm operation of a neuron.

The effect of $\alpha$-synuclein on neurotransmission and synaptic plasticity has been investigated both in knockout and in overexpressing conditions, where $\alpha$-synuclein has been reported to both promote and inhibit neurotransmitter release or have no effect at all. Although some studies report that $\alpha$-synuclein does not have 
J. Burré et al.

an effect on neurotransmitter release (Chandra et al. 2004; Watson et al. 2009; Burré et al. 2010), other studies report that $\alpha$-synuclein enhances synaptic transmission (Steidl et al. 2003; Liu et al. 2004; Gureviciene et al. 2007, 2009; GretenHarrison et al. 2010; Anwar et al. 2011; Vargas et al. 2014) or decreases release (Abeliovich et al. 2000; Cabin et al. 2002; Yavich et al. 2004, 2006; Larsen et al. 2006; Senior et al. 2008; GretenHarrison et al. 2010; Nemani et al. 2010; Wu et al. 2010). A recent study has reported an inhibitory effect of $\alpha$-synuclein on synapticvesicle endocytosis during intense stimulation, but not under basal levels (Busch et al. 2014; Vargas et al. 2014). Whether the inconsistent results obtained for the effects of $\alpha$-synuclein on neurotransmission and synaptic plasticity could be ascribed to the experimental models used and the investigated brain regions needs to be determined.

How does $\alpha$-synuclein exert its effect on the neurotransmission machinery? Within the presynaptic terminal, $\alpha$-synuclein is highly mobile, as shown by photobleaching experiments, and it disperses from synaptic vesicles upon stimulation (Fortin et al. 2005). $\alpha$-Synuclein modulates the mobility of synaptic vesicles between presynaptic boutons and maintains the overall size of the recycling pools at individual synapses (Scott and Roy 2012). It also organizes into multimers at synapses, which cluster synaptic vesicles, thereby restricting their motility (Wang et al. 2014) and likely attenuating exo/ endocytosis. Multimerization is triggered by membrane binding and mediates SNARE-complex chaperoning activity (Burré et al. 2014). Moreover, $\alpha$-synuclein clusters synaptic-vesicle mimics in vitro, via binding to the vesicles and synaptobrevin-2, and thereby prevents fusion of synaptic-vesicle mimics with plasma-membrane mimics (Fig. 6) (Diao et al. 2013), suggesting that $\alpha$-synuclein provides a buffer of synaptic vesicles without affecting neurotransmitter release itself. In vitro, $\alpha$-synuclein specifically inhibits vesicle docking without interfering with the fusion process (Lai et al. 2014). Overexpression causes accumulation of docked vesicles at synapses and smaller readily releasable pools (RRPs) (Larsen et al. 2006). Thus, the effect of $\alpha$-synuclein on neurotransmitter release is likely not mediated by directly affecting the release machinery, but by regulating vesicle pools within the presynaptic terminal.

\section{CONCLUDING REMARKS}

Although $\alpha$-synuclein has gained prominence for its role in neurodegenerative diseases called synucleinopathies, much about its cellular function(s) remains unclear, and little is known about how $\alpha$-synuclein becomes cytotoxic and causes neurodegeneration when it is mutated or overexpressed. Diverse studies have proposed myriad functions for $\alpha$-synuclein at locations ranging from the nucleus to mitochondria and nerve terminals. Of these, the strongest evidence has accumulated for the localization of $\alpha$-synuclein at nerve terminals, specifically on the highly curved membrane of synaptic vesicles. Misfolded $\alpha$-synuclein forms oligomers and aggregates that are believed to be toxic, and recent studies have revealed propagation of misfolded $\alpha$-synuclein between neurons. Nucleation and propagation of $\alpha$-synuclein misfolding, whether from the cytosolic pool or from the membranebound pool, remains controversial. There is now substantial evidence for toxicity of $\alpha$-synuclein oligomers, as well as evidence for either a benign or protective role of larger aggregates and, potentially, Lewy bodies. Which species of $\alpha$-synuclein is transferred from neuron to neuron, and how it is released, is entirely unknown and is a subject of intense research. Understanding how $\alpha$-synuclein localizes and functions in subcellular compartments will facilitate understanding of central questions, such as how $\alpha$-synuclein misfolds, which species of $\alpha$-synuclein are toxic, how these species are released and taken up by neurons, and how these species may nucleate new aggregates in a healthy cell. The subcellular localization-specific functions of $\alpha$-synuclein, such as those at nerve terminals, increase the possibility that pathological aggregation and inclusion of $\alpha$-synuclein into Lewy bodies depletes the protein from locations where it functions, which occurs in addition to the direct toxic effects of misfolded $\alpha$-synuclein aggregates. Thus, these are exciting times in $\alpha$-synuclein research, 
and much will likely be revealed about this fascinating molecule in the near future.

\section{ACKNOWLEDGMENTS}

This work is supported by the Morris K. Udall Center of Excellence for Parkinson's Disease Research (T.C.S.), in part by the National Institute of Neurological Disorders and Stroke (NINDS) (NS094733; T.C.S.), the Leon Levy Foundation (J.B.), the American Parkinson Disease Association (J.B.), the Alzheimer's Association (M.S.), the American Federation for Aging Research (M.S.), and the National Institute on Aging (NIA) (AG052505; M.S.).

\section{REFERENCES}

${ }^{*}$ Reference is also in this collection.

Abeliovich A, Schmitz Y, Farinas I, Choi-Lundberg D, Ho WH, Castillo PE, Shinsky N, Verdugo JM, Armanini M, Ryan A, et al. 2000. Mice lacking $\alpha$-synuclein display functional deficits in the nigrostriatal dopamine system. Neuron 25: 239-252.

Ahmad M, Attoub S, Singh MN, Martin FL, El-Agnaf OM. 2007. $\gamma$-Synuclein and the progression of cancer. FASEBJ 21: $3419-3430$.

Ahn BH, Rhim H, Kim SY, Sung YM, Lee MY, Choi JY, Wolozin B, Chang JS, Lee YH, Kwon TK, et al. 2002. $\alpha-$ Synuclein interacts with phospholipase D isozymes and inhibits pervanadate-induced phospholipase D activation in human embryonic kidney-293 cells. J Biol Chem 277: 12334-12342.

Ahn KJ, Paik SR, Chung KC, Kim J. 2006a. Amino acid sequence motifs and mechanistic features of the membrane translocation of $\alpha$-synuclein. J Neurochem 97: 265-279.

Ahn M, Kim S, Kang M, Ryu Y, Kim TD. 2006b. Chaperonelike activities of $\alpha$-synuclein: $\alpha$-synuclein assists enzyme activities of esterases. Biochem Biophys Res Commun 346: $1142-1149$.

Alfaro JF, Gong CX, Monroe ME, Aldrich JT, Clauss TR, Purvine SO, Wang Z, Camp DG II, Shabanowitz J, Stanley P, et al. 2012. Tandem mass spectrometry identifies many mouse brain O-GlcNAcylated proteins including EGF domain-specific O-GlcNAc transferase targets. Proc Natl Acad Sci 109: 7280-7285.

Alim MA, Hossain MS, Arima K, Takeda K, Izumiyama Y, Nakamura M, Kaji H, Shinoda T, Hisanaga Sueda K. 2002. Tubulin seeds $\alpha$-synuclein fibril formation. J Biol Chem 277: 2112-2117.

Alvarez-Erviti L, Rodriguez-Oroz MC, Cooper JM, Caballero C, Ferrer I, Obeso JA, Schapira AH. 2010. Chaperone-mediated autophagy markers in Parkinson disease brains. Arch Neurol 67: 1464-1472.
Anderson JP, Walker DE, Goldstein JM, de Laat R, Banducci K, Caccavello RJ, Barbour R, Huang J, Kling K, Lee M, et al. 2006. Phosphorylation of Ser-129 is the dominant pathological modification of $\alpha$-synuclein in familial and sporadic Lewy body disease. J Biol Chem 281: 29739-29752.

Anwar S, Peters O, Millership S, Ninkina N, Doig N, Connor-Robson N, Threlfell S, Kooner G, Deacon RM, Bannerman DM, et al. 2011. Functional alterations to the nigrostriatal system in mice lacking all three members of the synuclein family. J Neurosci 31: 7264-7274.

Arawaka S, Saito Y, Murayama S, Mori H. 1998. Lewy body in neurodegeneration with brain iron accumulation type 1 is immunoreactive for $\alpha$-synuclein. Neurology 51: $887-$ 889.

Askanas V, Engel WK, Alvarez RB, McFerrin J, Broccolini A. 2000. Novel immunolocalization of $\alpha$-synuclein in human muscle of inclusion-body myositis, regenerating and necrotic muscle fibers, and at neuromuscular junctions. J Neuropathol Exp Neurol 59: 592-598.

Baba M, Nakajo S, Tu PH, Tomita T, Nakaya K, Lee VM, Trojanowski JQ, Iwatsubo T. 1998. Aggregation of $\alpha$-synuclein in Lewy bodies of sporadic Parkinson's disease and dementia with Lewy bodies. Am J Pathol 152: 879-884.

Bandopadhyay R, Kingsbury AE, Muqit MM, Harvey K, Reid AR, Kilford L, Engelender S, Schlossmacher MG, Wood NW, Latchman DS, et al. 2005. Synphilin-1 and parkin show overlapping expression patterns in human brain and form aggresomes in response to proteasomal inhibition. Neurobiol Dis 20: 401-411.

Bandyopadhyay U, Cuervo AM. 2007. Chaperone-mediated autophagy in aging and neurodegeneration: Lessons from $\alpha$-synuclein. Exp Gerontol 42: 120-128.

Baptista MJ, O'Farrell C, Daya S, Ahmad R, Miller DW, Hardy J, Farrer MJ, Cookson MR. 2003. Co-ordinate transcriptional regulation of dopamine synthesis genes by $\alpha$-synuclein in human neuroblastoma cell lines. J Neurochem 85: 957-968.

Bartels T, Choi JG, Selkoe DJ. 2011. $\alpha$-Synuclein occurs physiologically as a helically folded tetramer that resists aggregation. Nature 477: 107-110.

Bartels T, Kim NC, Luth ES, Selkoe DJ. 2014. N- $\alpha$-acetylation of $\alpha$-synuclein increases its helical folding propensity, GM1 binding specificity and resistance to aggregation. PLoS ONE 9: e103727.

Bayer TA, Jakala P, Hartmann T, Egensperger R, Buslei R, Falkai P, Beyreuther K. 1999. Neural expression profile of $\alpha$-synuclein in developing human cortex. Neuroreport 10: 2799-2803.

Bennett MC, Bishop JF, Leng Y, Chock PB, Chase TN, Mouradian MM. 1999. Degradation of $\alpha$-synuclein by proteasome. J Biol Chem 274: 33855-33858.

Bertini I, Gupta YK, Luchinat C, Parigi G, Peana M, Sgheri L, Yuan J. 2007. Paramagnetism-based NMR restraints provide maximum allowed probabilities for the different conformations of partially independent protein domains. J Am Chem Soc 129: 12786-12794.

Bertoncini CW, Jung YS, Fernandez CO, Hoyer W, Griesinger C, Jovin TM, Zweckstetter M. 2005. Release of long-range tertiary interactions potentiates aggregation of natively unstructured $\alpha$-synuclein. Proc Natl Acad Sci 102: $1430-1435$. 
J. Burré et al.

Binolfi A, Theillet FX, Selenko P. 2012. Bacterial in-cell NMR of human $\alpha$-synuclein: A disordered monomer by nature? Biochem Soc Trans 40: 950-954.

Borbat P, Ramlall TF, Freed JH, Eliezer D. 2006. Inter-helix distances in lysophospholipid micelle-bound $\alpha$-synuclein from pulsed ESR measurements. J Am Chem Soc 128: 10004-10005.

Borghi R, Marchese R, Negro A, Marinelli L, Forloni G, Zaccheo D, Abbruzzese G, Tabaton M. 2000. Full length $\alpha$-synuclein is present in cerebrospinal fluid from Parkinson's disease and normal subjects. Neurosci Lett 287: $65-$ 67.

Botella JA, Bayersdorfer F, Schneuwly S. 2008. Superoxide dismutase overexpression protects dopaminergic neurons in a Drosophila model of Parkinson's disease. Neurobiol Dis 30: $65-73$.

Braak H, Ghebremedhin E, Rub U, Bratzke H, Del Tredici K. 2004. Stages in the development of Parkinson's diseaserelated pathology. Cell Tissue Res 318: 121-134.

Brown DR. 2007. Interactions between metals and $\alpha$-synuclein-Function or artefact? FEBS J 274: 3766-3774.

Buchman VL, Adu J, Pinon LG, Ninkina NN, Davies AM. 1998a. Persyn, a member of the synuclein family, influences neurofilament network integrity. Nat Neurosci 1: 101-103.

Buchman VL, Hunter HJ, Pinon LG, Thompson J, Privalova EM, Ninkina NN, Davies AM. 1998b. Persyn, a member of the synuclein family, has a distinct pattern of expression in the developing nervous system. J Neurosci 18: 9335-9341.

Burré J, Sharma M, Tsetsenis T, Buchman V, Etherton MR, Südhof TC. 2010. $\alpha$-Synuclein promotes SNARE-complex assembly in vivo and in vitro. Science 329: $1663-$ 1667.

Burré J, Sharma M, Südhof TC. 2012. Systematic mutagenesis of $\alpha$-synuclein reveals distinct sequence requirements for physiological and pathological activities. J Neurosci 32: 15227-15242.

Burré J, Vivona S, Diao J, Sharma M, Brunger AT, Südhof TC. 2013. Properties of native brain $\alpha$-synuclein. Nature 498: E4-E6; discussion E6-E7.

Burré J, Sharma M, Südhof TC. 2014. $\alpha$-Synuclein assembles into higher-order multimers upon membrane binding to promote SNARE complex formation. Proc Natl Acad Sci 111: E4274-E4283.

Burré J, Sharma M, Südhof TC. 2015. Definition of a molecular pathway mediating $\alpha$-synuclein neurotoxicity. J Neurosci 35: 5221-5232.

Busch DJ, Oliphint PA, Walsh RB, Banks SM, Woods WS George JM, Morgan JR. 2014. Acute increase of $\alpha$-synuclein inhibits synaptic vesicle recycling evoked during intense stimulation. Mol Biol Cell 25: 3926-3941.

Bussell R Jr, Eliezer D. 2003. A structural and functional role for 11-mer repeats in $\alpha$-synuclein and other exchangeable lipid binding proteins. J Mol Biol 329: 763-778.

Bussell R Jr, Ramlall TF, Eliezer D. 2005. Helix periodicity, topology, and dynamics of membrane-associated $\alpha$-synuclein. Protein Sci 14: 862-872.

Cabin DE, Shimazu K, Murphy D, Cole NB, Gottschalk W, McIlwain KL, Orrison B, Chen A, Ellis CE, Paylor R, et al. 2002. Synaptic vesicle depletion correlates with attenuat- ed synaptic responses to prolonged repetitive stimulation in mice lacking $\alpha$-synuclein. J Neurosci 22: 8797-8807.

Campbell BC, McLean CA, Culvenor JG, Gai WP, Blumbergs PC, Jakala P, Beyreuther K, Masters CL, Li QX. 2001. The solubility of $\alpha$-synuclein in multiple system atrophy differs from that of dementia with Lewy bodies and Parkinson's disease. J Neurochem 76: 87-96.

Chandra S, Chen X, Rizo J, Jahn R, Südhof TC. 2003. A broken $\alpha$-helix in folded $\alpha$-Synuclein. J Biol Chem 278: 15313-15318.

Chandra S, Fornai F, Kwon HB, Yazdani U, Atasoy D, Liu X, Hammer RE, Battaglia G, German DC, Castillo PE, et al. 2004. Double-knockout mice for $\alpha$ - and $\beta$-synucleins: Effect on synaptic functions. Proc Natl Acad Sci 101: 14966-14971.

Chandra S, Gallardo G, Fernandez-Chacon R, Schluter OM, Südhof TC. 2005. $\alpha$-Synuclein cooperates with CSP $\alpha$ in preventing neurodegeneration. Cell 123: 383-396.

Chen L, Feany MB. 2005. $\alpha$-Synuclein phosphorylation controls neurotoxicity and inclusion formation in a Drosophila model of Parkinson disease. Nat Neurosci 8: 657 663.

Chen L, Periquet M, Wang X, Negro A, McLean PJ, Hyman BT, Feany MB. 2009. Tyrosine and serine phosphorylation of $\alpha$-synuclein have opposing effects on neurotoxicity and soluble oligomer formation. J Clin Invest 119: 3257-3265.

Chen L, Wei Y, Wang X, He R. 2010. Ribosylation rapidly induces $\alpha$-synuclein to form highly cytotoxic molten globules of advanced glycation end products. PLoS ONE 5: e9052.

Chen RH, Wislet-Gendebien S, Samuel F, Visanji NP, Zhang G, Marsilio D, Langman T, Fraser PE, Tandon A. 2013. $\alpha$ Synuclein membrane association is regulated by the Rab3a recycling machinery and presynaptic activity. $J$ Biol Chem 288: 7438-7449.

Cherny D, Hoyer W, Subramaniam V, Jovin TM. 2004. Double-stranded DNA stimulates the fibrillation of $\alpha$-synuclein in vitro and is associated with the mature fibrils: An electron microscopy study. J Mol Biol 344: 929-938.

Chinta SJ, Mallajosyula JK, Rane A, Andersen JK. 2010. Mitochondrial $\alpha$-synuclein accumulation impairs complex I function in dopaminergic neurons and results in increased mitophagy in vivo. Neurosci Lett 486: 235-239.

Choubey V, Safiulina D, Vaarmann A, Cagalinec M, Wareski P, Kuum M, Zharkovsky A, Kaasik A. 2011. Mutant A53T $\alpha$-synuclein induces neuronal death by increasing mitochondrial autophagy. J Biol Chem 286: 10814-10824.

Chu Y, Kordower JH. 2007. Age-associated increases of $\alpha$ synuclein in monkeys and humans are associated with nigrostriatal dopamine depletion: Is this the target for Parkinson's disease? Neurobiol Dis 25: 134-149.

Clark J, Clore EL, Zheng K, Adame A, Masliah E, Simon DK. 2010. Oral $N$-acetyl-cysteine attenuates loss of dopaminergic terminals in $\alpha$-synuclein overexpressing mice. PLOS ONE 5: e12333.

Clavaguera F, Bolmont T, Crowther RA, Abramowski D, Frank S, Probst A, Fraser G, Stalder AK, Beibel M, Staufenbiel M, et al. 2009. Transmission and spreading of tauopathy in transgenic mouse brain. Nat Cell Biol 11: 909-913. 
Clayton DF, George JM. 1998. The synucleins: A family of proteins involved in synaptic function, plasticity, neurodegeneration and disease. Trends Neurosci 21: 249-254.

Clough RL, Stefanis L. 2007. A novel pathway for transcriptional regulation of $\alpha$-synuclein. FASEB J 21: 596-607.

Cole NB, Murphy DD, Grider T, Rueter S, Brasaemle D, Nussbaum RL. 2002. Lipid droplet binding and oligomerization properties of the Parkinson's disease protein $\alpha$-synuclein. J Biol Chem 277: 6344-6352.

Cole NB, Dieuliis D, Leo P, Mitchell DC, Nussbaum RL. 2008. Mitochondrial translocation of $\alpha$-synuclein is promoted by intracellular acidification. Exp Cell Res 314: 2076-2089.

Conway KA, Harper JD, Lansbury PT. 1998. Accelerated in vitro fibril formation by a mutant $\alpha$-synuclein linked to early-onset Parkinson disease. Nat Med 4: 1318-1320.

Conway KA, Lee SJ, Rochet JC, Ding TT, Harper JD, Williamson RE, Lansbury PT Jr. 2000. Accelerated oligomerization by Parkinson's disease linked $\alpha$-synuclein mutants. Ann NY Acad Sci 920: 42-45.

Cooper AA, Gitler AD, Cashikar A, Haynes CM, Hill KJ, Bhullar B, Liu K, Xu K, Strathearn KE, Liu F, et al. 2006. $\alpha$-Synuclein blocks ER-Golgi traffic and Rab1 rescues neuron loss in Parkinson's models. Science 313: 324-328.

Crowther RA, Jakes R, Spillantini MG, Goedert M. 1998. Synthetic filaments assembled from C-terminally truncated $\alpha$-synuclein. FEBS Lett 436: 309-312.

Cuervo AM, Stefanis L, Fredenburg R, Lansbury PT, Sulzer D. 2004. Impaired degradation of mutant $\alpha$-synuclein by chaperone-mediated autophagy. Science 305: $1292-$ 1295.

da Costa CA, Ancolio K, Checler F. 2000. Wild-type but not Parkinson's disease-related ala-53 $\rightarrow$ Thr mutant $\alpha$-syn uclein protects neuronal cells from apoptotic stimuli. $J$ Biol Chem 275: 24065-24069.

Dalfo E, Ferrer I. 2005. $\alpha$-synuclein binding to rab3a in multiple system atrophy. Neurosci Lett 380: 170-175.

Dalfo E, Gomez-Isla T, Rosa JL, Nieto Bodelon M, Cuadrado Tejedor M, Barrachina M, Ambrosio S, Ferrer I. 2004. Abnormal $\alpha$-synuclein interactions with Rab proteins in $\alpha$-synuclein A30P transgenic mice. J Neuropathol Exp Neurol 63: 302-313.

Danielson SR, Held JM, Schilling B, Oo M, Gibson BW, Andersen JK. 2009. Preferentially increased nitration of $\alpha$-synuclein at tyrosine-39 in a cellular oxidative model of Parkinson's disease. Anal Chem 81: 7823-7828.

Davidson WS, Jonas A, Clayton DF, George JM. 1998. Stabilization of $\alpha$-synuclein secondary structure upon binding to synthetic membranes. J Biol Chem 273: $9443-$ 9449.

Desplats P, Lee HJ, Bae EJ, Patrick C, Rockenstein E, Crews L, Spencer B, Masliah E, Lee SJ. 2009. Inclusion formation and neuronal cell death through neuron-to-neuron transmission of $\alpha$-synuclein. Proc Natl Acad Sci 106: 13010-13015.

Devi L, Raghavendran V, Prabhu BM, Avadhani NG, Anandatheerthavarada HK. 2008. Mitochondrial import and accumulation of $\alpha$-synuclein impair complex I in human dopaminergic neuronal cultures and Parkinson disease brain. J Biol Chem 283: 9089-9100.
Diao J, Burre J, Vivona S, Cipriano DJ, Sharma M, Kyoung M, Südhof TC, Brunger AT. 2013. Native $\alpha$-synuclein induces clustering of synaptic-vesicle mimics via binding to phospholipids and synaptobrevin-2/VAMP2. eLife 2: e00592.

Dikiy I, Eliezer D. 2014. N-terminal acetylation stabilizes Nterminal helicity in lipid- and micelle-bound $\alpha$-synuclein and increases its affinity for physiological membranes. $J$ Biol Chem 289: 3652-3665.

Ding TT, Lee SJ, Rochet JC, Lansbury PT Jr. 2002. Annular $\alpha$-synuclein protofibrils are produced when spherical protofibrils are incubated in solution or bound to brain-derived membranes. Biochemistry 41: 1020910217.

Dorval V, Fraser PE. 2006. Small ubiquitin-like modifier (SUMO) modification of natively unfolded proteins tau and $\alpha$-synuclein. J Biol Chem 281: 9919-9924.

Drescher M, Veldhuis G, van Rooijen BD, Milikisyants S, Subramaniam V, Huber M. 2008. Antiparallel arrangement of the helices of vesicle-bound $\alpha$-synuclein. J Am Chem Soc 130: 7796-7797.

Duda JE, Shah U, Arnold SE, Lee VM, Trojanowski JQ. 1999. The expression of $\alpha-, \beta$-, and $\gamma$-synucleins in olfactory mucosa from patients with and without neurodegenerative diseases. Exp Neurol 160: 515-522.

Dufty BM, Warner LR, Hou ST, Jiang SX, Gomez-Isla T, Leenhouts KM, Oxford JT, Feany MB, Masliah E, Rohn TT. 2007. Calpain-cleavage of $\alpha$-synuclein: Connecting proteolytic processing to disease-linked aggregation. Am J Pathol 170: 1725-1738.

El-Agnaf OM, Jakes R, Curran MD, Wallace A. 1998. Effects of the mutations Ala30 to Pro and Ala53 to Thr on the physical and morphological properties of $\alpha$-synuclein protein implicated in Parkinson's disease. FEBS Lett 440: $67-70$.

El-Agnaf OM, Salem SA, Paleologou KE, Cooper LJ, Fullwood NJ, Gibson MJ, Curran MD, Court JA, Mann DM, Ikeda S, et al. 2003. $\alpha$-Synuclein implicated in Parkinson's disease is present in extracellular biological fluids, including human plasma. FASEB J 17: 1945-1947.

El-Agnaf OM, Salem SA, Paleologou KE, Curran MD, Gibson MJ, Court JA, Schlossmacher MG, Allsop D. 2006. Detection of oligomeric forms of $\alpha$-synuclein protein in human plasma as a potential biomarker for Parkinson's disease. FASEB J 20: 419-425.

Eliezer D, Kutluay E, Bussell R Jr, Browne G. 2001. Conformational properties of $\alpha$-synuclein in its free and lipidassociated states. J Mol Biol 307: 1061-1073.

Ellis CE, Schwartzberg PL, Grider TL, Fink DW, Nussbaum RL. 2001. $\alpha$-Synuclein is phosphorylated by members of the Src family of protein-tyrosine kinases. J Biol Chem 276: $3879-3884$

Ellis CE, Murphy EJ, Mitchell DC, Golovko MY, Scaglia F, Barcelo-Coblijn GC, Nussbaum RL. 2005. Mitochondrial lipid abnormality and electron transport chain impairment in mice lacking $\alpha$-synuclein. Mol Cell Biol 25: 10190-10201.

Emmanouilidou E, Melachroinou K, Roumeliotis T, Garbis SD, Ntzouni M, Margaritis LH, Stefanis L, Vekrellis K. 2010a. Cell-produced $\alpha$-synuclein is secreted in a calcium-dependent manner by exosomes and impacts neuronal survival. J Neurosci 30: 6838-6851. 
J. Burré et al.

Emmanouilidou E, Stefanis L, Vekrellis K. 2010b. Cell-produced $\alpha$-synuclein oligomers are targeted to, and impair, the $26 \mathrm{~S}$ proteasome. Neurobiol Aging 31: 953-968.

Engelender S, Kaminsky Z, Guo X, Sharp AH, Amaravi RK, Kleiderlein JJ, Margolis RL, Troncoso JC, Lanahan AA, Worley PF, et al. 1999. Synphilin-1 associates with $\alpha$-synuclein and promotes the formation of cytosolic inclusions. Nat Genet 22: 110-114.

Fares MB, Ait-Bouziad N, Dikiy I, Mbefo MK, Jovicic A, Kiely A, Holton JL, Lee SJ, Gitler AD, Eliezer D, et al. 2014. The novel Parkinson's disease linked mutation G51D attenuates in vitro aggregation and membrane binding of $\alpha$-synuclein, and enhances its secretion and nuclear localization in cells. Hum Mol Genet 23: 44914509.

Fauvet B, Fares MB, Samuel F, Dikiy I, Tandon A, Eliezer D, Lashuel HA. 2012a. Characterization of semisynthetic and naturally $\mathrm{N} \alpha$-acetylated $\alpha$-synuclein in vitro and in intact cells: Implications for aggregation and cellular properties of $\alpha$-synuclein. J Biol Chem 287: $28243-$ 28262.

Fauvet B, Mbefo MK, Fares MB, Desobry C, Michael S, Ardah MT, Tsika E, Coune P, Prudent M, Lion N, et al. 2012b. $\alpha$-Synuclein in central nervous system and from erythrocytes, mammalian cells, and Escherichia coli exists predominantly as disordered monomer. J Biol Chem 287: 15345-15364.

Ferese R, Modugno N, Campopiano R, Santilli M, Zampatti S, Giardina E, Nardone A, Postorivo D, Fornai F, Novelli G, et al. 2015. Four copies of SNCA responsible for autosomal dominant Parkinson's disease in two Italian siblings. Parkinsons Dis 2015: 546462.

Fernandez CO, Hoyer W, Zweckstetter M, Jares-Erijman EA, Subramaniam V, Griesinger C, Jovin TM. 2004. NMR of $\alpha$-synuclein-polyamine complexes elucidates the mechanism and kinetics of induced aggregation. EMBO J 23: 2039-2046.

Fortin DL, Troyer MD, Nakamura K, Kubo S, Anthony MD, Edwards RH. 2004. Lipid rafts mediate the synaptic localization of $\alpha$-synuclein. J Neurosci 24: 6715-6723.

Fortin DL, Nemani VM, Voglmaier SM, Anthony MD, Ryan TA, Edwards RH. 2005. Neural activity controls the synaptic accumulation of $\alpha$-synuclein. J Neurosci 25: 10913 10921.

Fredenburg RA, Rospigliosi C, Meray RK, Kessler JC, Lashuel HA, Eliezer D, Lansbury PT Jr. 2007. The impact of the E46K mutation on the properties of $\alpha$-synuclein in its monomeric and oligomeric states. Biochemistry 46: $7107-7118$.

Frost B, Jacks RL, Diamond MI. 2009. Propagation of tau misfolding from the outside to the inside of a cell. J Biol Chem 284: 12845-12852.

Fujiwara H, Hasegawa M, Dohmae N, Kawashima A, Masliah E, Goldberg MS, Shen J, Takio K, Iwatsubo T. 2002. $\alpha$-Synuclein is phosphorylated in synucleinopathy lesions. Nat Cell Biol 4: 160-164.

Gai WP, Power JH, Blumbergs PC, Blessing WW. 1998. Multiple-system atrophy: A new $\alpha$-synuclein disease? Lancet 352: $547-548$

Galvin JE, Schuck TM, Lee VM, Trojanowski JQ. 2001. Differential expression and distribution of $\alpha$-, $\beta$-, and $\gamma$ - synuclein in the developing human substantia nigra. Exp Neurol 168: 347-355.

George JM, Jin H, Woods WS, Clayton DF. 1995. Characterization of a novel protein regulated during the critical period for song learning in the zebra finch. Neuron 15: 361-372.

Georgieva ER, Ramlall TF, Borbat PP, Freed JH, Eliezer D. 2008. Membrane-bound $\alpha$-synuclein forms an extended helix: Long-distance pulsed ESR measurements using vesicles, bicelles, and rodlike micelles. J Am Chem Soc 130: $12856-12857$.

Ghosh D, Sahay S, Ranjan P, Salot S, Mohite GM, Singh PK, Dwivedi S, Carvalho E, Banerjee R, Kumar A, et al. 2014 The newly discovered Parkinson's disease associated Finnish mutation (A53E) attenuates $\alpha$-synuclein aggregation and membrane binding. Biochemistry 53: 64196421.

Giasson BI, Duda JE, Murray IV, Chen Q, Souza JM, Hurtig HI, Ischiropoulos H, Trojanowski JQ, Lee VM. 2000. Oxidative damage linked to neurodegeneration by selective $\alpha$-synuclein nitration in synucleinopathy lesions. Science 290: 985-989.

Giasson BI, Forman MS, Higuchi M, Golbe LI, Graves CL Kotzbauer PT, Trojanowski JQ, Lee VM. 2003. Initiation and synergistic fibrillization of tau and $\alpha$-synuclein. Science 300: 636-640.

Gitler AD, Shorter J. 2007. Prime time for $\alpha$-synuclein. J Neurosci 27: 2433-2434.

Gomez-Santos C, Ferrer I, Santidrian AF, Barrachina M, Gil J, Ambrosio S. 2003. Dopamine induces autophagic cell death and $\alpha$-synuclein increase in human neuroblastoma SH-SY5Y cells. J Neurosci Res 73: 341-350.

Gomez-Santos C, Barrachina M, Gimenez-Xavier P, Dalfo E, Ferrer I, Ambrosio S. 2005. Induction of C/EBP $\beta$ and GADD153 expression by dopamine in human neuroblastoma cells. Relationship with $\alpha$-synuclein increase and cell damage. Brain Res Bull 65: 87-95.

Gomez-Tortosa E, Newell K, Irizarry MC, Sanders JL, Hyman BT. 2000. $\alpha$-Synuclein immunoreactivity in dementia with Lewy bodies: Morphological staging and comparison with ubiquitin immunostaining. Acta Neuropathol 99: 352-357.

Gorbatyuk OS, Li S, Nguyen FN, Manfredsson FP, Kondrikova G, Sullivan LF, Meyers C, Chen W, Mandel RJ, Muzyczka N. 2010. $\alpha$-Synuclein expression in rat substantia nigra suppresses phospholipase D2 toxicity and nigral neurodegeneration. Mol Ther 18: 1758-1768.

Gosavi N, Lee HJ, Lee JS, Patel S, Lee SJ. 2002. Golgi fragmentation occurs in the cells with prefibrillar $\alpha$-synuclein aggregates and precedes the formation of fibrillar inclusion. J Biol Chem 277: 48984-48992.

Greenbaum EA, Graves CL, Mishizen-Eberz AJ, Lupoli MA, Lynch DR, Englander SW, Axelsen PH, Giasson BI. 2005. The E46K mutation in $\alpha$-synuclein increases amyloid fibril formation. J Biol Chem 280: 7800-7807.

Greten-Harrison B, Polydoro M, Morimoto-Tomita M, Diao L, Williams AM, Nie EH, Makani S, Tian N, Castillo PE, Buchman VL, et al. 2010. $\alpha \beta \gamma$-Synuclein triple knockout mice reveal age-dependent neuronal dysfunction. Proc Natl Acad Sci 107: 19573-19578.

Guo JT, Chen AQ, Kong Q, Zhu H, Ma CM, Qin C. 2008. Inhibition of vesicular monoamine transporter-2 activity 
in $\alpha$-synuclein stably transfected SH-SY5Y cells. Cell Mol Neurobiol 28: 35-47.

Gureviciene I, Gurevicius K, Tanila H. 2007. Role of $\alpha$-synuclein in synaptic glutamate release. Neurobiol Dis 28: 83-89.

Gureviciene I, Gurevicius K, Tanila H. 2009. Aging and $\alpha$ synuclein affect synaptic plasticity in the dentate gyrus. $J$ Neural Transm 116: 13-22.

Haggerty T, Credle J, Rodriguez O, Wills J, Oaks AW, Masliah E, Sidhu A. 2011. Hyperphosphorylated tau in an $\alpha$-synuclein-overexpressing transgenic model of Parkinson's disease. Eur J Neurosci 33: 1598-1610.

* Hasegawa M, Nonaka T, Masuda-Suzukake M. 2016. $\alpha$-Synuclein: Experimental pathology. Cold Spring Harb Perspect Med 6: a024273.

Hashimoto M, Yoshimoto M, Sisk A, Hsu LJ, Sundsmo M, Kittel A, Saitoh T, Miller A, Masliah E. 1997. NACP, a synaptic protein involved in Alzheimer's disease, is differentially regulated during megakaryocyte differentiation. Biochem Biophys Res Commun 237: 611-616.

Hodara R, Norris EH, Giasson BI, Mishizen-Eberz AJ, Lynch DR, Lee VM-Y, Ischiropoulos H. 2004. Functional consequences of $\alpha$-synuclein tyrosine nitration: Diminished binding to lipid vesicles and increased fibril formation. J Biol Chem 279: 47746-47753.

Hoyer W, Cherny D, Subramaniam V, Jovin TM. 2004. Impact of the acidic $\mathrm{C}$-terminal region comprising amino acids $109-140$ on $\alpha$-synuclein aggregation in vitro. Biochemistry 43: 16233-16242.

Hsu LJ, Mallory M, Xia Y, Veinbergs I, Hashimoto M, Yoshimoto M, Thal LJ, Saitoh T, Masliah E. 1998. Expression pattern of synucleins (non-A $\beta$ component of Alzheimer's disease amyloid precursor protein $/ \alpha$-synuclein) during murine brain development. J Neurochem 71: $338-344$.

Hsu LJ, Sagara Y, Arroyo A, Rockenstein E, Sisk A, Mallory M, Wong J, Takenouchi T, Hashimoto M, Masliah E. 2000. $\alpha$-Synuclein promotes mitochondrial deficit and oxidative stress. Am J Pathol 157: 401-410.

Ibanez P, Bonnet AM, Debarges B, Lohmann E, Tison F Pollak P, Agid Y, Durr A, Brice A. 2004. Causal relation between $\alpha$-synuclein gene duplication and familial Parkinson's disease. Lancet 364: 1169-1171.

Inglis KJ, Chereau D, Brigham EF, Chiou SS, Schobel S, Frigon NL, Yu M, Caccavello RJ, Nelson S, Motter R, et al. 2009. Polo-like kinase 2 (PLK2) phosphorylates $\alpha$ synuclein at serine 129 in central nervous system. J Biol Chem 284: 2598-2602.

Ishii A, Nonaka T, Taniguchi S, Saito T, Arai T, Mann D, Iwatsubo T, Hisanaga S, Goedert M, Hasegawa M. 2007. Casein kinase 2 is the major enzyme in brain that phosphorylates Ser 129 of human $\alpha$-synuclein: Implication for $\alpha$-synucleinopathies. FEBS Lett 581: 4711-4717.

Iwai A, Masliah E, Yoshimoto M, Ge N, Flanagan L, de Silva HA, Kittel A, Saitoh T. 1995. The precursor protein of non-A $\beta$ component of Alzheimer's disease amyloid is a presynaptic protein of the central nervous system. Neuron 14: $467-475$.

Iwata A, Maruyama M, Akagi T, Hashikawa T, Kanazawa I, Tsuji S, Nukina N. 2003. $\alpha$-Synuclein degradation by serine protease neurosin: Implication for pathogenesis of synucleinopathies. Hum Mol Genet 12: 2625-2635.
Jakes R, Spillantini MG, Goedert M. 1994. Identification of two distinct synucleins from human brain. FEBS Lett 345: $27-32$.

Jao CC, Der-Sarkissian A, Chen J, Langen R. 2004. Structure of membrane-bound $\alpha$-synuclein studied by site-directed spin labeling. Proc Natl Acad Sci 101: 8331-8336.

Jao CC, Hegde BG, Chen J, Haworth IS, Langen R. 2008. Structure of membrane-bound $\alpha$-synuclein from site-directed spin labeling and computational refinement. Proc Natl Acad Sci 105: 19666-19671.

Jenco JM, Rawlingson A, Daniels B, Morris AJ. 1998. Regulation of phospholipase D2: Selective inhibition of mammalian phospholipase D isoenzymes by $\alpha$ - and $\beta$-synucleins. Biochemistry 37: 4901-4909.

Jensen PH, Hager H, Nielsen MS, Hojrup P, Gliemann J, Jakes R. 1999. $\alpha$-Synuclein binds to Tau and stimulates the protein kinase A-catalyzed tau phosphorylation of serine residues 262 and 356. J Biol Chem 274: 2548125489.

Ji H, Liu YE, Jia T, Wang M, Liu J, Xiao G, Joseph BK, Rosen C, Shi YE. 1997. Identification of a breast cancer-specific gene, BCSG1, by direct differential cDNA sequencing. Cancer Res 57: 759-764.

Jia T, Liu YE, Liu J, Shi YE. 1999. Stimulation of breast cancer invasion and metastasis by synuclein $\gamma$. Cancer Res 59: 742-747.

Jo E, McLaurin J, Yip CM, St George-Hyslop P, Fraser PE. 2000. $\alpha$-Synuclein membrane interactions and lipid specificity. J Biol Chem 275: 34328-34334.

Jo E, Fuller N, Rand RP, St George-Hyslop P, Fraser PE. 2002. Defective membrane interactions of familial Parkinson's disease mutant A30P $\alpha$-synuclein. J Mol Biol 315: 799807.

Jucker M, Walker LC. 2011. Pathogenic protein seeding in Alzheimer disease and other neurodegenerative disorders. Ann Neurol 70: 532-540.

Junn E, Mouradian MM. 2002. Human $\alpha$-synuclein overexpression increases intracellular reactive oxygen species levels and susceptibility to dopamine. Neurosci Lett 320: $146-150$.

Kahle PJ, Neumann M, Ozmen L, Muller V, Jacobsen H, Schindzielorz A, Okochi M, Leimer U, van Der Putten $\mathrm{H}$, Probst A, et al. 2000. Subcellular localization of wildtype and Parkinson's disease-associated mutant $\alpha$-synuclein in human and transgenic mouse brain. $J$ Neurosci 20: 6365-6373.

Kahle PJ, Neumann M, Ozmen L, Muller V, Jacobsen H, Spooren W, Fuss B, Mallon B, Macklin WB, Fujiwara H, et al. 2002. Hyperphosphorylation and insolubility of $\alpha$ synuclein in transgenic mouse oligodendrocytes. $E M B O$ Rep 3: 583-588.

Kamp F, Beyer K. 2006. Binding of $\alpha$-synuclein affects the lipid packing in bilayers of small vesicles. J Biol Chem 281: 9251-9259.

Kamp F, Exner N, Lutz AK, Wender N, Hegermann J, Brunner B, Nuscher B, Bartels T, Giese A, Beyer K, et al. 2010 Inhibition of mitochondrial fusion by $\alpha$-synuclein is rescued by PINK1, Parkin and DJ-1. EMBO J 29: 35713589.

Kanda S, Bishop JF, Eglitis MA, Yang Y, Mouradian MM. 2000. Enhanced vulnerability to oxidative stress by $\alpha$ - 
J. Burré et al.

synuclein mutations and C-terminal truncation. Neuroscience 97: 279-284.

Kang L, Moriarty GM, Woods LA, Ashcroft AE, Radford SE Baum J. 2012. N-terminal acetylation of $\alpha$-synuclein induces increased transient helical propensity and decreased aggregation rates in the intrinsically disordered monomer. Protein Sci 21: 911-917.

Kasai T, Tokuda T, Yamaguchi N, Watanabe Y, Kametani F, Nakagawa M, Mizuno T. 2008. Cleavage of normal and pathological forms of $\alpha$-synuclein by neurosin in vitro. Neurosci Lett 436: 52-56.

Kholodilov NG, Neystat M, Oo TF, Lo SE, Larsen KE, Sulzer D, Burke RE. 1999. Increased expression of rat synuclein in the substantia nigra pars compacta identified by mRNA differential display in a model of developmental target injury. J Neurochem 73: 2586-2599.

Kiely AP, Asi YT, Kara E, Limousin P, Ling H, Lewis P, Proukakis C, Quinn N, Lees AJ, Hardy J, et al. 2013. $\alpha$-Synucleinopathy associated with G51D SNCA mutation: A link between Parkinson's disease and multiple system atrophy? Acta Neuropathol 125: 753-769.

Kim J. 1997. Evidence that the precursor protein of non-A $\beta$ component of Alzheimer's disease amyloid (NACP) has an extended structure primarily composed of randomcoil. Mol Cells 7: 78-83.

Kim TD, Paik SR, Yang CH, Kim J. 2000. Structural changes in $\alpha$-synuclein affect its chaperone-like activity in vitro. Protein Sci 9: 2489-2496.

Kim TD, Paik SR, Yang CH. 2002. Structural and functional implications of C-terminal regions of $\alpha$-synuclein. Biochemistry 41: 13782-13790.

Kim S, Jeon BS, Heo C, Im PS, Ahn TB, Seo JH, Kim HS, Park CH, Choi SH, Cho SH, et al. 2004a. $\alpha$-Synuclein induces apoptosis by altered expression in human peripheral lymphocyte in Parkinson's disease. FASEB J 18: 1615-1617.

Kim TD, Choi E, Rhim H, Paik SR, Yang CH. 2004b. $\alpha-$ Synuclein has structural and functional similarities to small heat shock proteins. Biochem Biophys Res Commun 324: $1352-1359$.

Kim EJ, Sung JY, Lee HJ, Rhim H, Hasegawa M, Iwatsubo T, Min do S, Kim J, Paik SR, Chung KC. 2006. Dyrk1A phosphorylates $\alpha$-synuclein and enhances intracellular inclusion formation. J Biol Chem 281: 33250-33257.

Kim YM, Jang WH, Quezado MM, Oh Y, Chung KC, Junn E, Mouradian MM. 2011. Proteasome inhibition induces $\alpha$ synuclein SUMOylation and aggregate formation. $\mathrm{J} \mathrm{Neu}$ rol Sci 307: 157-161.

Kirik D, Rosenblad C, Burger C, Lundberg C, Johansen TE Muzyczka N, Mandel RJ, Bjorklund A. 2002. Parkinsonlike neurodegeneration induced by targeted overexpression of $\alpha$-synuclein in the nigrostriatal system. J Neurosci 22: $2780-2791$.

Kontopoulos E, Parvin JD, Feany MB. 2006. $\alpha$-Synuclein acts in the nucleus to inhibit histone acetylation and promote neurotoxicity. Hum Mol Genet 15: 3012-3023.

Kordower JH, Chu Y, Hauser RA, Olanow CW, Freeman TB. 2008. Transplanted dopaminergic neurons develop PD pathologic changes: A second case report. Mov Disord 23: $2303-2306$.
Kotzbauer PT, Giasson BI, Kravitz AV, Golbe LI, Mark MH, Trojanowski JQ, Lee VM. 2004. Fibrillization of $\alpha$-synuclein and tau in familial Parkinson's disease caused by the A53T $\alpha$-synuclein mutation. Exp Neurol 187: 279-288.

Kruger R, Kuhn W, Muller T, Woitalla D, Graeber M, Kosel S, Przuntek H, Epplen JT, Schols L, Riess O. 1998. Ala30Pro mutation in the gene encoding $\alpha$-synuclein in Parkinson's disease. Nat Genet 18: 106-108.

Krumova P, Meulmeester E, Garrido M, Tirard M, Hsiao HH, Bossis G, Urlaub H, Zweckstetter M, Kugler S, Melchior F, et al. 2011. Sumoylation inhibits $\alpha$-synuclein aggregation and toxicity. J Cell Biol 194: 49-60.

Kurowska Z, Englund E, Widner H, Lindvall O, Li JY, Brundin P. 2011. Signs of degeneration in 12-22-year old grafts of mesencephalic dopamine neurons in patients with Parkinson's disease. J Parkinsons Dis 1: 83-92.

Lai Y, Kim S, Varkey J, Lou X, Song JK, Diao J, Langen R, Shin YK. 2014. Nonaggregated $\alpha$-synuclein influences SNARE-dependent vesicle docking via membrane binding. Biochemistry 53: 3889-3896.

Larsen KE, Schmitz Y, Troyer MD, Mosharov E, Dietrich P, Quazi AZ, Savalle M, Nemani V, Chaudhry FA, Edwards $\mathrm{RH}$, et al. 2006. $\alpha$-Synuclein overexpression in PC12 and chromaffin cells impairs catecholamine release by interfering with a late step in exocytosis. J Neurosci 26: 11915 11922.

Lashuel HA, Petre BM, Wall J, Simon M, Nowak RJ, Walz T, Lansbury PT Jr. 2002. $\alpha$-Synuclein, especially the Parkinson's disease-associated mutants, forms pore-like annular and tubular protofibrils. J Mol Biol 322: 1089-1102.

Lavedan C. 1998. The synuclein family. Genome Res 8: $871-$ 880.

Lavedan C, Leroy E, Dehejia A, Buchholtz S, Dutra A, Nussbaum RL, Polymeropoulos MH. 1998. Identification, localization and characterization of the human $\gamma$-synuclein gene. Hum Genet 103: 106-112.

Lee HJ, Khoshaghideh F, Patel S, Lee SJ. 2004. Clearance of $\alpha$-synuclein oligomeric intermediates via the lysosomal degradation pathway. J Neurosci 24: 1888-1896.

Lee HJ, Patel S, Lee SJ. 2005. Intravesicular localization and exocytosis of $\alpha$-synuclein and its aggregates. J Neurosci 25: 6016-6024.

Lee HJ, Khoshaghideh F, Lee S, Lee SJ. 2006a. Impairment of microtubule-dependent trafficking by overexpression of $\alpha$-synuclein. Eur J Neurosci 24: 3153-3162.

Lee PH, Lee G, Park HJ, Bang OY, Joo IS, Huh K. 2006b. The plasma $\alpha$-synuclein levels in patients with Parkinson's disease and multiple system atrophy. J Neural Transm 113: $1435-1439$.

Lee JT, Wheeler TC, Li L, Chin LS. 2008. Ubiquitination of $\alpha$-synuclein by Siah-1 promotes $\alpha$-synuclein aggregation and apoptotic cell death. Hum Mol Genet 17: 906-917.

Lee D, Park CW, Paik SR, Choi KY. 2009. The modification of $\alpha$-synuclein by dicarbonyl compounds inhibits its fibril-forming process. Biochim Biophys Acta 1794: 421430.

Leroy E, Boyer R, Auburger G, Leube B, Ulm G, Mezey E, Harta G, Brownstein MJ, Jonnalagada S, Chernova T, et al. 1998. The ubiquitin pathway in Parkinson's disease. Nature 395: 451-452. 
Levin J, Giese A, Boetzel K, Israel L, Hogen T, Nubling G, Kretzschmar H, Lorenzl S. 2009. Increased $\alpha$-synuclein aggregation following limited cleavage by certain matrix metalloproteinases. Exp Neurol 215: 201-208.

Lewis KA, Su Y, Jou O, Ritchie C, Foong C, Hynan LS, White CL III, Thomas PJ, Hatanpaa KJ. 2010. Abnormal neurites containing $\mathrm{C}$-terminally truncated $\alpha$-synuclein are present in Alzheimer's disease without conventional Lewy body pathology. Am J Pathol 177: 3037-3050.

Li QX, Campbell BC, McLean CA, Thyagarajan D, Gai WP, Kapsa RM, Beyreuther K, Masters CL, Culvenor JG. 2002. Platelet $\alpha$ - and $\gamma$-synucleins in Parkinson's disease and normal control subjects. J Alzheimers Dis 4: 309-315.

Li W, West N, Colla E, Pletnikova O, Troncoso JC, Marsh L, Dawson TM, Jakala P, Hartmann T, Price DL, et al. 2005. Aggregation promoting C-terminal truncation of $\alpha$-synuclein is a normal cellular process and is enhanced by the familial Parkinson's disease-linked mutations. Proc Natl Acad Sci 102: 2162-2167.

Li WW, Yang R, Guo JC, Ren HM, Zha XL, Cheng JS, Cai DF. 2007. Localization of $\alpha$-synuclein to mitochondria within midbrain of mice. Neuroreport 18: 1543-1546.

Li JY, Englund E, Holton JL, Soulet D, Hagell P, Lees AJ, Lashley T, Quinn NP, Rehncrona S, Bjorklund A, et al. 2008. Lewy bodies in grafted neurons in subjects with Parkinson's disease suggest host-to-graft disease propagation. Nat Med 14: 501-503.

Liani E, Eyal A, Avraham E, Shemer R, Szargel R, Berg D, Bornemann A, Riess O, Ross CA, Rott R, et al. 2004. Ubiquitylation of synphilin- 1 and $\alpha$-synuclein by SIAH and its presence in cellular inclusions and Lewy bodies imply a role in Parkinson's disease. Proc Natl Acad Sci 101: $5500-5505$.

Lindersson E, Beedholm R, Hojrup P, Moos T, Gai W, Hendil KB, Jensen PH. 2004. Proteasomal inhibition by $\alpha$-synuclein filaments and oligomers. J Biol Chem 279: 12924 12934.

Lindvall O, Sawle G, Widner H, Rothwell JC, Bjorklund A, Brooks D, Brundin P, Frackowiak R, Marsden CD, Odin P, et al. 1994. Evidence for long-term survival and function of dopaminergic grafts in progressive Parkinson's disease. Ann Neurol 35: 172-180.

Liu Y, Fallon L, Lashuel HA, Liu Z, Lansbury PT Jr. 2002. The UCH-L1 gene encodes two opposing enzymatic activities that affect $\alpha$-synuclein degradation and Parkinson's disease susceptibility. Cell 111: 209-218.

Liu S, Ninan I, Antonova I, Battaglia F, Trinchese F, Narasanna A, Kolodilov N, Dauer W, Hawkins RD, Arancio O. 2004. $\alpha$-Synuclein produces a long-lasting increase in neurotransmitter release. EMBO J 23: 4506-4516.

Liu CW, Giasson BI, Lewis KA, Lee VM, Demartino GN, Thomas PJ. 2005a. A precipitating role for truncated $\alpha$ synuclein and the proteasome in $\alpha$-synuclein aggregation: Implications for pathogenesis of Parkinson disease. J Biol Chem 280: 22670-22678.

Liu H, Liu W, Wu Y, Zhou Y, Xue R, Luo C, Wang L, Zhao W, Jiang JD, Liu J. 2005b. Loss of epigenetic control of synuclein- $\gamma$ gene as a molecular indicator of metastasis in a wide range of human cancers. Cancer Res 65: 7635-7643.

Liu G, Zhang C, Yin J, Li X, Cheng F, Li Y, Yang H, Ueda K, Chan P, Yu S. 2009. $\alpha$-Synuclein is differentially expressed in mitochondria from different rat brain regions and dose-dependently down-regulates complex I activity. Neurosci Lett 454: 187-192.

Liu Z, Yu Y, Li X, Ross CA, Smith WW. 2011. Curcumin protects against $\mathrm{A} 53 \mathrm{~T} \alpha$-synuclein-induced toxicity in a PC12 inducible cell model for Parkinsonism. Pharmacol Res 63: 439-444.

Loeb V, Yakunin E, Saada A, Sharon R. 2010. The transgenic overexpression of $\alpha$-synuclein and not its related pathology associates with complex I inhibition. J Biol Chem 285: 7334-7343.

Lou H, Montoya SE, Alerte TN, Wang J, Wu J, Peng X, Hong CS, Friedrich EE, Mader SA, Pedersen CJ, et al. 2010 Serine 129 phosphorylation reduces the ability of $\alpha$-synuclein to regulate tyrosine hydroxylase and protein phosphatase 2A in vitro and in vivo. J Biol Chem 285: $17648-$ 17661.

Ltic S, Perovic M, Mladenovic A, Raicevic N, Ruzdijic S, Rakic L, Kanazir S. 2004. $\alpha$-Synuclein is expressed in different tissues during human fetal development. J Mol Neurosci 22: 199-204.

Lucke C, Gantz DL, Klimtchuk E, Hamilton JA. 2006. Interactions between fatty acids and $\alpha$-synuclein. J Lipid Res 47: 1714-1724.

Luk KC, Kehm V, Carroll J, Zhang B, O’Brien P, Trojanowski JQ, Lee VM. 2012. Pathological $\alpha$-synuclein transmission initiates Parkinson-like neurodegeneration in nontransgenic mice. Science 338: 949-953.

Maltsev AS, Ying J, Bax A. 2012. Impact of N-terminal acetylation of $\alpha$-synuclein on its random coil and lipid binding properties. Biochemistry 51: 5004-5013.

Manning-Bog AB, McCormack AL, Li J, Uversky VN, Fink AL, Di Monte DA. 2002. The herbicide paraquat causes up-regulation and aggregation of $\alpha$-synuclein in mice: Paraquat and $\alpha$-synuclein. J Biol Chem 277: 1641-1644.

Maraganore DM, de Andrade M, Elbaz A, Farrer MJ, Ioannidis JP, Kruger R, Rocca WA, Schneider NK, Lesnick TG, Lincoln SJ, et al. 2006. Collaborative analysis of $\alpha$-synuclein gene promoter variability and Parkinson disease. JAMA 296: 661-670.

Maroteaux L, Campanelli JT, Scheller RH. 1988. Synuclein A neuron-specific protein localized to the nucleus and presynaptic nerve terminal. J Neurosci 8: 2804-2815.

Marotta NP, Cherwien CA, Abeywardana T, Pratt MR. 2012. O-GlcNAc modification prevents peptide-dependent acceleration of $\alpha$-synuclein aggregation. Chembiochem 13: 2665-2670.

Martin LJ, Pan Y, Price AC, Sterling W, Copeland NG, Jenkins NA, Price DL, Lee MK. 2006. Parkinson's disease $\alpha$ synuclein transgenic mice develop neuronal mitochondrial degeneration and cell death. J Neurosci 26: 41-50.

Martin-Clemente B, Alvarez-Castelao B, Mayo I, Sierra AB, Diaz V, Milan M, Farinas I, Gomez-Isla T, Ferrer I, Castano JG. 2004. $\alpha$-Synuclein expression levels do not significantly affect proteasome function and expression in mice and stably transfected PC12 cell lines. J Biol Chem 279: 52984-52990.

Masliah E, Rockenstein E, Veinbergs I, Mallory M, Hashimoto M, Takeda A, Sagara Y, Sisk A, Mucke L. 2000. Dopaminergic loss and inclusion body formation in $\alpha$ synuclein mice: Implications for neurodegenerative disorders. Science 287: 1265-1269. 
J. Burré et al.

Masuda-Suzukake M, Nonaka T, Hosokawa M, Oikawa T, Arai T, Akiyama H, Mann DM, Hasegawa M. 2013. Prion-like spreading of pathological $\alpha$-synuclein in brain. Brain 136: $1128-1138$

Mbefo MK, Paleologou KE, Boucharaba A, Oueslati A, Schell H, Fournier M, Olschewski D, Yin G, Zweckstetter M, Masliah E, et al. 2010. Phosphorylation of synucleins by members of the Polo-like kinase family. J Biol Chem 285: 2807-2822.

McFarland MA, Ellis CE, Markey SP, Nussbaum RL. 2008. Proteomics analysis identifies phosphorylation-dependent $\alpha$-synuclein protein interactions. Mol Cell Proteomics 7: 2123-2137.

McLean PJ, Kawamata H, Hyman BT. 2001. $\alpha$-Synucleinenhanced green fluorescent protein fusion proteins form proteasome sensitive inclusions in primary neurons. Neuroscience 104: 901-912.

Mezey E, Dehejia AM, Harta G, Tresser N, Suchy SF, Nussbaum RL, Brownstein MJ, Polymeropoulos MH. 1998. a Synuclein is present in Lewy bodies in sporadic Parkinson's disease. Mol Psychiatry 3: 493-499.

Middleton ER, Rhoades E. 2010. Effects of curvature and composition on $\alpha$-synuclein binding to lipid vesicles. Biophys J 99: 2279-2288.

Mishizen-Eberz AJ, Guttmann RP, Giasson BI, Day GA III, Hodara R, Ischiropoulos H, Lee VM, Trojanowski JQ, Lynch DR. 2003. Distinct cleavage patterns of normal and pathologic forms of $\alpha$-synuclein by calpain I in vitro. J Neurochem 86: 836-847.

Mori F, Tanji K, Yoshimoto M, Takahashi H, Wakabayashi K. 2002. Immunohistochemical comparison of $\alpha$ - and $\beta$ synuclein in adult rat central nervous system. Brain Res 941: $118-126$.

Munch G, Luth HJ, Wong A, Arendt T, Hirsch E, Ravid R, Riederer P. 2000. Crosslinking of $\alpha$-synuclein by advanced glycation endproducts-An early pathophysiological step in Lewy body formation? J Chem Neuroanat 20: $253-257$.

Muntane G, Ferrer I, Martinez-Vicente M. 2012. $\alpha$-Synuclein phosphorylation and truncation are normal events in the adult human brain. Neuroscience 200: 106-119.

Murray IV, Giasson BI, Quinn SM, Koppaka V, Axelsen PH, Ischiropoulos H, Trojanowski JQ, Lee VM. 2003. Role of $\alpha$-synuclein carboxy-terminus on fibril formation in vitro. Biochemistry 42: 8530-8540.

Nakai M, Fujita M, Waragai M, Sugama S, Wei J, Akatsu H, Ohtaka-Maruyama C, Okado H, Hashimoto M. 2007. Expression of $\alpha$-synuclein, a presynaptic protein implicated in Parkinson's disease, in erythropoietic lineage. Biochem Biophys Res Commun 358: 104-110.

Nakajo S, Omata K, Aiuchi T, Shibayama T, Okahashi I, Ochiai H, Nakai Y, Nakaya K, Nakamura Y. 1990. Purification and characterization of a novel brain-specific 14kDa protein. J Neurochem 55: 2031-2038.

Nakajo S, Tsukada K, Omata K, Nakamura Y, Nakaya K. 1993. A new brain-specific $14-\mathrm{kDa}$ protein is a phosphoprotein. Its complete amino acid sequence and evidence for phosphorylation. Eur J Biochem 217: 1057-1063.

Nakajo S, Shioda S, Nakai Y, Nakaya K. 1994. Localization of phosphoneuroprotein 14 (PNP 14) and its mRNA expression in rat brain determined by immunocytochem- istry and in situ hybridization. Brain Res Mol Brain Res 27: $81-86$.

Nakamura T, Yamashita H, Takahashi T, Nakamura S. 2001. Activated Fyn phosphorylates $\alpha$-synuclein at tyrosine residue 125. Biochem Biophys Res Commun 280: $1085-$ 1092.

Nakamura K, Nemani VM, Wallender EK, Kaehlcke K, Ott M, Edwards RH. 2008. Optical reporters for the conformation of $\alpha$-synuclein reveal a specific interaction with mitochondria. J Neurosci 28: 12305-12317.

Nakamura K, Nemani VM, Azarbal F, Skibinski G, Levy JM, Egami K, Munishkina L, Zhang J, Gardner B, Wakabayashi J, et al. 2011. Direct membrane association drives mitochondrial fission by the Parkinson disease-associated protein $\alpha$-synuclein. J Biol Chem 286: 20710-20726.

Nalls MA, Plagnol V, Hernandez DG, Sharma M, Sheerin UM, Saad M, Simon-Sanchez J, Schulte C, Lesage S, Sveinbjornsdottir S, et al. 2011. Imputation of sequence variants for identification of genetic risks for Parkinson's disease: A meta-analysis of genome-wide association studies. Lancet 377: 641-649.

Narhi L, Wood SJ, Steavenson S, Jiang Y, Wu GM, Anafi D, Kaufman SA, Martin F, Sitney K, Denis P, et al. 1999. Both familial Parkinson's disease mutations accelerate $\alpha$-synuclein aggregation. J Biol Chem 274: 9843-9846.

Negro A, Brunati AM, Donella-Deana A, Massimino ML, Pinna LA. 2002. Multiple phosphorylation of $\alpha$-synuclein by protein tyrosine kinase Syk prevents eosin-induced aggregation. FASEB J 16: 210-212.

Nemani VM, Lu W, Berge V, Nakamura K, Onoa B, Lee MK, Chaudhry FA, Nicoll RA, Edwards RH. 2010. Increased expression of $\alpha$-synuclein reduces neurotransmitter release by inhibiting synaptic vesicle reclustering after endocytosis. Neuron 65: 66-79.

Nickel W. 2003. The mystery of nonclassical protein secretion. A current view on cargo proteins and potential export routes. Eur J Biochem 270: 2109-2119.

Nielsen MS, Vorum H, Lindersson E, Jensen PH. 2001. $\mathrm{Ca}^{2+}$ binding to $\alpha$-synuclein regulates ligand binding and oligomerization. J Biol Chem 276: 22680-22684.

Ninkina NN, Alimova-Kost MV, Paterson JW, Delaney L, Cohen BB, Imreh S, Gnuchev NV, Davies AM, Buchman VL. 1998. Organization, expression and polymorphism of the human persyn gene. Hum Mol Genet 7: 14171424.

Nonaka T, Iwatsubo T, Hasegawa M. 2005. Ubiquitination of $\alpha$-synuclein. Biochemistry 44: 361-368.

Norris EH, Giasson BI, Ischiropoulos H, Lee VM. 2003. Effects of oxidative and nitrative challenges on $\alpha$-synuclein fibrillogenesis involve distinct mechanisms of protein modifications. J Biol Chem 278: 27230-27240.

Nuscher B, Kamp F, Mehnert T, Odoy S, Haass C, Kahle PJ, Beyer K. 2004. $\alpha$-Synuclein has a high affinity for packing defects in a bilayer membrane: A thermodynamics study. J Biol Chem 279: 21966-21975.

Ogawa K, Yamada T, Tsujioka Y, Taguchi J, Takahashi M, Tsuboi Y, Fujino Y, Nakajima M, Yamamoto T, Akatsu $\mathrm{H}$, et al. 2000. Localization of a novel type trypsin-like serine protease, neurosin, in brain tissues of Alzheimer's disease and Parkinson's disease. Psychiatry Clin Neurosci 54: 419-426. 
Oh Y, Kim YM, Mouradian MM, Chung KC. 2011. Human Polycomb protein 2 promotes $\alpha$-synuclein aggregate formation through covalent SUMOylation. Brain Res 1381: $78-89$.

Okochi M, Walter J, Koyama A, Nakajo S, Baba M, Iwatsubo T, Meijer L, Kahle PJ, Haass C. 2000. Constitutive phosphorylation of the Parkinson's disease associated $\alpha$-synuclein. J Biol Chem 275: 390-397.

Olanow CW, Schapira AH, Agid Y. 2003. Neuroprotection for Parkinson's disease: Prospects and promises. Ann Neurol 53: S1-S2.

Ostrerova N, Petrucelli L, Farrer M, Mehta N, Choi P, Hardy J, Wolozin B. 1999. $\alpha$-Synuclein shares physical and functional homology with $14-3-3$ proteins. J Neurosci 19: 5782-5791.

Ouberai MM, Wang J, Swann MJ, Galvagnion C, Guilliams T, Dobson CM, Welland ME. 2013. $\alpha$-Synuclein senses lipid packing defects and induces lateral expansion of lipids leading to membrane remodeling. J Biol Chem 288: 20883-20895.

Outeiro TF, Kontopoulos E, Altmann SM, Kufareva I, Strathearn KE, Amore AM, Volk CB, Maxwell MM, Rochet JC, McLean PJ, et al. 2007. Sirtuin 2 inhibitors rescue $\alpha$-synuclein-mediated toxicity in models of Parkinson's disease. Science 317: 516-519.

Padmaraju V, Bhaskar JJ, Prasada Rao UJ, Salimath PV, Rao KS. 2011. Role of advanced glycation on aggregation and DNA binding properties of $\alpha$-synuclein. J Alzheimers Dis 24: $211-221$.

Paik SR, Shin HJ, Lee JH, Chang CS, Kim J. 1999. Copper(II)-induced self-oligomerization of $\alpha$-synuclein. $B i$ ochem J 340: 821-828.

Paillusson S, Clairembault T, Biraud M, Neunlist M, Derkinderen P. 2013. Activity-dependent secretion of $\alpha$-synuclein by enteric neurons. J Neurochem 125: 512-517.

Paleologou KE, Oueslati A, Shakked G, Rospigliosi CC, Kim HY, Lamberto GR, Fernandez CO, Schmid A, Chegini F, Gai WP, et al. 2010. Phosphorylation at S87 is enhanced in synucleinopathies, inhibits $\alpha$-synuclein oligomerization, and influences synuclein-membrane interactions. $J$ Neurosci 30: 3184-3198.

Park SM, Jung HY, Chung KC, Rhim H, Park JH, Kim J. 2002. Stress-induced aggregation profiles of GST- $\alpha$-synuclein fusion proteins: Role of the C-terminal acidic tail of $\alpha$-synuclein in protein thermosolubility and stability. Biochemistry 41: 4137-4146.

Park SM, Ahn KJ, Jung HY, Park JH, Kim J. 2004. Effects of novel peptides derived from the acidic tail of synuclein (ATS) on the aggregation and stability of fusion proteins. Protein Eng Des Sel 17: 251-260.

Pasanen P, Myllykangas L, Siitonen M, Raunio A, Kaakkola S, Lyytinen J, Tienari PJ, Poyhonen M, Paetau A. 2014. A novel $\alpha$-synuclein mutation A53E associated with atypical multiple system atrophy and Parkinson's disease-type pathology. Neurobiol Aging 35: 2180.e1-2180.e15.

Pawar AP, Dubay KF, Zurdo J, Chiti F, Vendruscolo M, Dobson CM. 2005. Prediction of "aggregation-prone" and "aggregation-susceptible" regions in proteins associated with neurodegenerative diseases. J Mol Biol 350: 379392.
Payton JE, Perrin RJ, Woods WS, George JM. 2004. Structural determinants of PLD2 inhibition by $\alpha$-synuclein. $J$ Mol Biol 337: 1001-1009.

Peng X, Tehranian R, Dietrich P, Stefanis L, Perez RG. 2005. $\alpha$-Synuclein activation of protein phosphatase $2 \mathrm{~A}$ reduces tyrosine hydroxylase phosphorylation in dopaminergic cells. J Cell Sci 118: 3523-3530.

Perez RG, Waymire JC, Lin E, Liu JJ, Guo F, Zigmond MJ. 2002. A role for $\alpha$-synuclein in the regulation of dopamine biosynthesis. J Neurosci 22: 3090-3099.

Perrin RJ, Woods WS, Clayton DF, George JM. 2000. Interaction of human $\alpha$-synuclein and Parkinson's disease variants with phospholipids. Structural analysis using site-directed mutagenesis. J Biol Chem 275: 3439334398.

Petersen K, Olesen OF, Mikkelsen JD. 1999. Developmental expression of $\alpha$-synuclein in rat hippocampus and cerebral cortex. Neuroscience 91: 651-659.

Petkova AT, Leapman RD, Guo Z, Yau WM, Mattson MP, Tycko R. 2005. Self-propagating, molecular-level polymorphism in Alzheimer's $\beta$-amyloid fibrils. Science 307: 262-265.

Petrucelli L, O’Farrell C, Lockhart PJ, Baptista M, Kehoe K, Vink L, Choi P, Wolozin B, Farrer M, Hardy J, et al. 2002. Parkin protects against the toxicity associated with mutant $\alpha$-synuclein: Proteasome dysfunction selectively affects catecholaminergic neurons. Neuron 36: 1007-1019.

Polymeropoulos MH, Lavedan C, Leroy E, Ide SE, Dehejia A, Dutra A, Pike B, Root H, Rubenstein J, Boyer R, et al. 1997. Mutation in the $\alpha$-synuclein gene identified in families with Parkinson's disease. Science 276: $2045-$ 2047.

Pronin AN, Morris AJ, Surguchov A, Benovic JL. 2000. Synucleins are a novel class of substrates for G-protein-coupled receptor kinases. J Biol Chem 275: 26515-26522.

Proukakis C, Dudzik CG, Brier T, MacKay DS, Cooper JM, Millhauser GL, Houlden H, Schapira AH. 2013. A novel $\alpha$-synuclein missense mutation in Parkinson disease. Neurology 80: 1062-1064.

Qing H, Wong W, McGeer EG, McGeer PL. 2009. Lrrk2 phosphorylates $\alpha$ synuclein at serine 129: Parkinson disease implications. Biochem Biophys Res Commun 387: $149-152$.

Qureshi HY, Paudel HK. 2011. Parkinsonian neurotoxin 1-methyl-4-phenyl-1,2,3,6-tetrahydropyridine (MPTP) and $\alpha$-synuclein mutations promote Tau protein phosphorylation at Ser262 and destabilize microtubule cytoskeleton in vitro. J Biol Chem 286: 5055-5068.

Rekas A, Adda CG, Andrew Aquilina J, Barnham KJ, Sunde M, Galatis D, Williamson NA, Masters CL, Anders RF, Robinson CV, et al. 2004. Interaction of the molecular chaperone $\alpha$ B-crystallin with $\alpha$-synuclein: Effects on amyloid fibril formation and chaperone activity. J Mol Biol 340: 1167-1183.

Ribeiro CS, Carneiro K, Ross CA, Menezes JR, Engelender S. 2002. Synphilin-1 is developmentally localized to synaptic terminals, and its association with synaptic vesicles is modulated by $\alpha$-synuclein. J Biol Chem 277: 2392723933.

Rochet JC, Conway KA, Lansbury PT Jr. 2000. Inhibition of fibrillization and accumulation of prefibrillar oligomers 
J. Burré et al.

in mixtures of human and mouse $\alpha$-synuclein. Biochemistry 39: 10619-10626.

Rott R, Szargel R, Haskin J, Shani V, Shainskaya A, Manov I, Liani E, Avraham E, Engelender S. 2008. Monoubiquitylation of $\alpha$-synuclein by seven in absentia homolog (SIAH) promotes its aggregation in dopaminergic cells J Biol Chem 283: 3316-3328.

Schell H, Hasegawa T, Neumann M, Kahle PJ. 2009. Nuclear and neuritic distribution of serine-129 phosphorylated $\alpha$-synuclein in transgenic mice. Neuroscience 160: 796804.

Scott D, Roy S. 2012. $\alpha$-Synuclein inhibits intersynaptic vesicle mobility and maintains recycling-pool homeostasis. J Neurosci 32: 10129-10135.

Senior SL, Ninkina N, Deacon R, Bannerman D, Buchman VL, Cragg SJ, Wade-Martins R. 2008. Increased striatal dopamine release and hyperdopaminergic-like behaviour in mice lacking both $\alpha$-synuclein and $\gamma$-synuclein. Eur J Neurosci 27: 947-957.

Serpell LC, Berriman J, Jakes R, Goedert M, Crowther RA. 2000. Fiber diffraction of synthetic $\alpha$-synuclein filaments shows amyloid-like cross- $\beta$ conformation. Proc Natl Acad Sci 97: 4897-4902.

Sevcsik E, Trexler AJ, Dunn JM, Rhoades E. 2011. Allostery in a disordered protein: Oxidative modifications to $\alpha$ synuclein act distally to regulate membrane binding. $J$ Am Chem Soc 133: 7152-7158.

Sevlever D, Jiang P, Yen SH. 2008. Cathepsin D is the main lysosomal enzyme involved in the degradation of $\alpha$-synuclein and generation of its carboxy-terminally truncated species. Biochemistry 47: 9678-9687.

Shahpasandzadeh H, Popova B, Kleinknecht A, Fraser PE, Outeiro TF, Braus GH. 2014. Interplay between sumoylation and phosphorylation for protection against $\alpha$-synuclein inclusions. J Biol Chem 289: 31224-31240.

Shaikh S, Nicholson LF. 2008. Advanced glycation end products induce in vitro cross-linking of $\alpha$-synuclein and accelerate the process of intracellular inclusion body formation. J Neurosci Res 86: 2071-2082.

Sharon R, Goldberg MS, Bar-Josef I, Betensky RA, Shen J, Selkoe DJ. 2001. $\alpha$-Synuclein occurs in lipid-rich high molecular weight complexes, binds fatty acids, and shows homology to the fatty acid-binding proteins. Proc Natl Acad Sci 98: 9110-9115.

Shimura H, Hattori N, Kubo S, Mizuno Y, Asakawa S, Minoshima S, Shimizu N, Iwai K, Chiba T, Tanaka K, et al. 2000. Familial Parkinson disease gene product, parkin, is a ubiquitin-protein ligase. Nat Genet 25: 302-305.

Shin EC, Cho SE, Lee DK, Hur MW, Paik SR, Park JH, Kim J. 2000. Expression patterns of $\alpha$-synuclein in human hematopoietic cells and in Drosophila at different developmental stages. Mol Cells 10: 65-70.

Singleton AB, Farrer M, Johnson J, Singleton A, Hague S, Kachergus J, Hulihan M, Peuralinna T, Dutra A, Nussbaum R, et al. 2003. $\alpha$-Synuclein locus triplication causes Parkinson's disease. Science 302: 841.

Smith WW, Jiang H, Pei Z, Tanaka Y, Morita H, Sawa A Dawson VL, Dawson TM, Ross CA. 2005. Endoplasmic reticulum stress and mitochondrial cell death pathways mediate A53T mutant $\alpha$-synuclein-induced toxicity. Hum Mol Genet 14: 3801-3811.
Snyder H, Mensah K, Theisler C, Lee J, Matouschek A, Wolozin B. 2003. Aggregated and monomeric $\alpha$-synuclein bind to the $S 6^{\prime}$ proteasomal protein and inhibit proteasomal function. J Biol Chem 278: 11753-11759.

Soper JH, Kehm V, Burd CG, Bankaitis VA, Lee VM. 2011. Aggregation of $\alpha$-synuclein in S. cerevisiae is associated with defects in endosomal trafficking and phospholipid biosynthesis. J Mol Neurosci 43: 391-405.

Souza JM, Giasson BI, Chen Q, Lee VM, Ischiropoulos H. 2000. Dityrosine cross-linking promotes formation of stable $\alpha$-synuclein polymers. Implication of nitrative and oxidative stress in the pathogenesis of neurodegenerative synucleinopathies. J Biol Chem 275: $18344-$ 18349.

Spillantini MG, Schmidt ML, Lee VM, Trojanowski JQ, Jakes R, Goedert M. 1997. $\alpha$-Synuclein in Lewy bodies. Nature 388: 839-840.

Spillantini MG, Crowther RA, Jakes R, Hasegawa M, Goedert M. 1998. $\alpha$-Synuclein in filamentous inclusions of Lewy bodies from Parkinson's disease and dementia with Lewy bodies. Proc Natl Acad Sci 95: 6469-6473.

Stefanis L, Larsen KE, Rideout HJ, Sulzer D, Greene LA. 2001. Expression of A53T mutant but not wild-type $\alpha$ synuclein in PC12 cells induces alterations of the ubiquitin-dependent degradation system, loss of dopamine release, and autophagic cell death. J Neurosci 21: 95499560.

Steidl JV, Gomez-Isla T, Mariash A, Ashe KH, Boland LM. 2003. Altered short-term hippocampal synaptic plasticity in mutant $\alpha$-synuclein transgenic mice. Neuroreport 14: 219-223.

Stichel CC, Zhu XR, Bader V, Linnartz B, Schmidt S, Lubbert H. 2007. Mono- and double-mutant mouse models of Parkinson's disease display severe mitochondrial damage. Hum Mol Genet 16: 2377-2393.

Sung JY, Kim J, Paik SR, Park JH, Ahn YS, Chung KC. 2001. Induction of neuronal cell death by Rab5A-dependent endocytosis of $\alpha$-synuclein. J Biol Chem 276: 27441 27448.

Sung JY, Park SM, Lee CH, Um JW, Lee HJ, Kim J, Oh YJ, Lee ST, Paik SR, Chung KC. 2005. Proteolytic cleavage of extracellular secreted $\alpha$-synuclein via matrix metalloproteinases. J Biol Chem 280: 25216-25224.

Takahashi T, Yamashita H, Nakamura T, Nagano Y, Nakamura S. 2002. Tyrosine 125 of $\alpha$-synuclein plays a critical role for dimerization following nitrative stress. Brain Res 938: 73-80.

Takahashi M, Kanuka H, Fujiwara H, Koyama A, Hasegawa M, Miura M, Iwatsubo T. 2003a. Phosphorylation of $\alpha$ synuclein characteristic of synucleinopathy lesions is recapitulated in $\alpha$-synuclein transgenic Drosophila. Neurosci Lett 336: 155-158.

Takahashi T, Yamashita H, Nagano Y, Nakamura T, Ohmori H, Avraham H, Avraham S, Yasuda M, Matsumoto M 2003b. Identification and characterization of a novel Pyk2/related adhesion focal tyrosine kinase-associated protein that inhibits $\alpha$-synuclein phosphorylation. $J$ Biol Chem 278: 42225-42233.

Takahashi M, Ko LW, Kulathingal J, Jiang P, Sevlever D, Yen SH. 2007. Oxidative stress-induced phosphorylation, degradation and aggregation of $\alpha$-synuclein are linked 
to upregulated CK2 and cathepsin D. Eur J Neurosci 26: $863-874$.

Tamo W, Imaizumi T, Tanji K, Yoshida H, Mori F, Yoshimoto M, Takahashi H, Fukuda I, Wakabayashi K, Satoh K. 2002. Expression of $\alpha$-synuclein, the precursor of nonamyloid $\beta$ component of Alzheimer's disease amyloid, in human cerebral blood vessels. Neurosci Lett 326: 5-8.

Tanaka Y, Engelender S, Igarashi S, Rao RK, Wanner T, Tanzi RE, Sawa A, LD V, Dawson TM, Ross CA. 2001. Inducible expression of mutant $\alpha$-synuclein decreases proteasome activity and increases sensitivity to mitochondria-dependent apoptosis. Hum Mol Genet 10: 919-926.

Tetzlaff JE, Putcha P, Outeiro TF, Ivanov A, Berezovska O, Hyman BT, McLean PJ. 2008. CHIP targets toxic $\alpha$-synuclein oligomers for degradation. J Biol Chem 283: 17962-17968.

Thayanidhi N, Helm JR, Nycz DC, Bentley M, Liang Y, Hay JC. 2010. $\alpha$-Synuclein delays endoplasmic reticulum (ER)-to-Golgi transport in mammalian cells by antagonizing ER/Golgi SNAREs. Mol Biol Cell 21: 1850-1863.

Theillet FX, Binolfi A, Bekei B, Martorana A, Rose HM, Stuiver M, Verzini S, Lorenz D, van Rossum M, Goldfarb D, et al. 2016. Structural disorder of monomeric $\alpha$-synuclein persists in mammalian cells. Nature 530: 45-50.

Tobe T, Nakajo S, Tanaka A, Mitoya A, Omata K, Nakaya K, Tomita M, Nakamura Y. 1992. Cloning and characterization of the cDNA encoding a novel brain-specific $14-\mathrm{kDa}$ protein. J Neurochem 59: 1624-1629.

Tofaris GK, Layfield R, Spillantini MG. 2001. $\alpha$-Synuclein metabolism and aggregation is linked to ubiquitin-independent degradation by the proteasome. FEBS Lett 509: $22-26$.

* Tofaris GK, Goedert M, Spillantini MG. 2016. The transcellular propagation and intracellular trafficking of $\alpha$ synuclein. Cold Spring Harb Perspect Med doi: 10.1101/ cshperspect.a024380.

Tokuda T, Qureshi MM, Ardah MT, Varghese S, Shehab SA, Kasai T, Ishigami N, Tamaoka A, Nakagawa M, El-Agnaf OM. 2010. Detection of elevated levels of $\alpha$-synuclein oligomers in CSF from patients with Parkinson disease. Neurology 75: 1766-1772.

Trexler AJ, Rhoades E. 2009. $\alpha$-Synuclein binds large unilamellar vesicles as an extended helix. Biochemistry 48: 2304-2306.

Ueda K, Fukushima H, Masliah E, Xia Y, Iwai A, Yoshimoto M, Otero DA, Kondo J, Ihara Y, Saitoh T. 1993. Molecular cloning of cDNA encoding an unrecognized component of amyloid in Alzheimer disease. Proc Natl Acad Sci 90: 11282-11286.

Ulmer TS, Bax A, Cole NB, Nussbaum RL. 2005. Structure and dynamics of micelle-bound human $\alpha$-synuclein. $J$ Biol Chem 280: 9595-9603.

Uversky VN. 2007. Neuropathology, biochemistry, and biophysics of $\alpha$-synuclein aggregation. J Neurochem 103: $17-37$.

Vargas KJ, Makani S, Davis T, Westphal CH, Castillo PE, Chandra SS. 2014. Synucleins regulate the kinetics of synaptic vesicle endocytosis. J Neurosci 34: 9364-9376.

Varkey J, Isas JM, Mizuno N, Jensen MB, Bhatia VK, Jao CC Petrlova J, Voss JC, Stamou DG, Steven AC, et al. 2010. Membrane curvature induction and tubulation are com- mon features of synucleins and apolipoproteins. J Biol Chem 285: 32486-32493.

Vila M, Vukosavic S, Jackson-Lewis V, Neystat M, Jakowec M, Przedborski S. 2000. $\alpha$-Synuclein up-regulation in substantia nigra dopaminergic neurons following administration of the parkinsonian toxin MPTP. J Neurochem 74: 721-729.

Volles MJ, Lee SJ, Rochet JC, Shtilerman MD, Ding TT, Kessler JC, Lansbury PT Jr. 2001. Vesicle permeabilization by protofibrillar $\alpha$-synuclein: Implications for the pathogenesis and treatment of Parkinson's disease. Biochemistry 40: 7812-7819.

Volpicelli-Daley LA, Luk KC, Patel TP, Tanik SA, Riddle DM, Stieber A, Meaney DF, Trojanowski JQ, Lee VM. 2011 Exogenous $\alpha$-synuclein fibrils induce Lewy body pathology leading to synaptic dysfunction and neuron death. Neuron 72: 57-71.

Wakabayashi K, Matsumoto K, Takayama K, Yoshimoto M, Takahashi H. 1997. NACP, a presynaptic protein, immunoreactivity in Lewy bodies in Parkinson's disease. Neurosci Lett 239: 45-48.

Wang Z, Udeshi ND, O’Malley M, Shabanowitz J, Hunt DF, Hart GW. 2010. Enrichment and site mapping of Olinked $\mathrm{N}$-acetylglucosamine by a combination of chemical/enzymatic tagging, photochemical cleavage, and electron transfer dissociation mass spectrometry. $\mathrm{Mol}$ Cell Proteomics 9: 153-160.

Wang W, Perovic I, Chittuluru J, Kaganovich A, Nguyen LT, Liao J, Auclair JR, Johnson D, Landeru A, Simorellis AK, et al. 2011. A soluble $\alpha$-synuclein construct forms a dynamic tetramer. Proc Natl Acad Sci 108: 17797-17802.

Wang L, Das U, Scott DA, Tang Y, McLean PJ, Roy S. 2014. $\alpha$ Synuclein multimers cluster synaptic vesicles and attenuate recycling. Curr Biol 24: 2319-2326.

Wassef R, Haenold R, Hansel A, Brot N, Heinemann SH, Hoshi T. 2007. Methionine sulfoxide reductase A and a dietary supplement $S$-methyl-L-cysteine prevent Parkinson's-like symptoms. J Neurosci 27: 12808-12816.

Watson JB, Hatami A, David H, Masliah E, Roberts K, Evans CE, Levine MS. 2009. Alterations in corticostriatal synaptic plasticity in mice overexpressing human $\alpha$-synuclein. Neuroscience 159: 501-513.

Waxman EA, Giasson BI. 2008. Specificity and regulation of casein kinase-mediated phosphorylation of $\alpha$-synuclein. J Neuropathol Exp Neurol 67: 402-416.

Webb JL, Ravikumar B, Atkins J, Skepper JN, Rubinsztein DC. 2003. $\alpha$-Synuclein is degraded by both autophagy and the proteasome. J Biol Chem 278: 25009-25013.

Weinreb PH, Zhen W, Poon AW, Conway KA, Lansbury PT Jr. 1996. NACP, a protein implicated in Alzheimer's disease and learning, is natively unfolded. Biochemistry 35: 13709-13715.

Westphal CH, Chandra SS. 2013. Monomeric synucleins generate membrane curvature. J Biol Chem 288: 18291840 .

Winklhofer KF, Haass C. 2010. Mitochondrial dysfunction in Parkinson's disease. Biochim Biophys Acta 1802: 29 44.

Winslow AR, Chen CW, Corrochano S, Acevedo-Arozena A, Gordon DE, Peden AA, Lichtenberg M, Menzies FM, Ravikumar B, Imarisio S, et al. 2010. $\alpha$-Synuclein impairs 
J. Burré et al.

macroautophagy: Implications for Parkinson's disease. $J$ Cell Biol 190: 1023-1037.

Withers GS, George JM, Banker GA, Clayton DF. 1997. Delayed localization of synelfin (synuclein, NACP) to presynaptic terminals in cultured rat hippocampal neurons. Brain Res Dev Brain Res 99: 87-94.

* Woerman AL, Watts JC, Aoyagi A, Giles K, Middleton LT, Prusiner SB. 2017. $\alpha$-Synuclein: Multiple system atrophy prions. Cold Spring Harb Perspect Med doi: 10.110/ cshperspect.a024588.

Woods WS, Boettcher JM, Zhou DH, Kloepper KD, Hartman KL, Ladror DT, Qi Z, Rienstra CM, George JM. 2007. Conformation-specific binding of $\alpha$-synuclein to novel protein partners detected by phage display and NMR spectroscopy. J Biol Chem 282: 34555-34567.

Wu KP, Kim S, Fela DA, Baum J. 2008. Characterization of conformational and dynamic properties of natively unfolded human and mouse $\alpha$-synuclein ensembles by NMR: implication for aggregation. J Mol Biol 378: 1104-1115.

Wu N, Joshi PR, Cepeda C, Masliah E, Levine MS. 2010. $\alpha$ Synuclein overexpression in mice alters synaptic communication in the corticostriatal pathway. J Neurosci Res 88: 1764-1776.

Wu B, Liu Q, Duan C, Li Y, Yu S, Chan P, Ueda K, Yang H. 2011. Phosphorylation of $\alpha$-synuclein upregulates tyrosine hydroxylase activity in MN9D cells. Acta Histochem 113: 32-35.

Xilouri M, Vogiatzi T, Vekrellis K, Park D, Stefanis L. 2009. Aberrant $\alpha$-synuclein confers toxicity to neurons in part through inhibition of chaperone-mediated autophagy. PLoS ONE 4: e5515.

Yamin G, Uversky VN, Fink AL. 2003. Nitration inhibits fibrillation of human $\alpha$-synuclein in vitro by formation of soluble oligomers. FEBS Lett 542: 147-152.

Yavich L, Tanila H, Vepsalainen S, Jakala P. 2004. Role of $\alpha$ synuclein in presynaptic dopamine recruitment. J Neurosci 24: $11165-11170$.
Yavich L, Jakala P, Tanila H. 2006. Abnormal compartmentalization of norepinephrine in mouse dentate gyrus in $\alpha$-synuclein knockout and A30P transgenic mice. J Neurochem 99: 724-732.

Yonetani M, Nonaka T, Masuda M, Inukai Y, Oikawa T, Hisanaga S, Hasegawa M. 2009. Conversion of wildtype $\alpha$-synuclein into mutant-type fibrils and its propagation in the presence of A30P mutant. J Biol Chem 284: 7940-7950.

Yu S, Zuo X, Li Y, Zhang C, Zhou M, Zhang YA, Ueda K, Chan P. 2004. Inhibition of tyrosine hydroxylase expression in $\alpha$-synuclein-transfected dopaminergic neuronal cells. Neurosci Lett 367: 34-39.

Yu S, Li X, Liu G, Han J, Zhang C, Li Y, Xu S, Liu C, Gao Y, Yang H, et al. 2007. Extensive nuclear localization of $\alpha$-synuclein in normal rat brain neurons revealed by a novel monoclonal antibody. Neuroscience 145: 539-555.

Zarranz JJ, Alegre J, Gomez-Esteban JC, Lezcano E, Ros R, Ampuero I, Vidal L, Hoenicka J, Rodriguez O, Atares B, et al. 2004. The new mutation, E46K, of $\alpha$-synuclein causes Parkinson and Lewy body dementia. Ann Neurol 55: 164-173.

Zhang W, Wang T, Pei Z, Miller DS, Wu X, Block ML, Wilson B, Zhou Y, Hong JS, Zhang J. 2005. Aggregated $\alpha$-synuclein activates microglia: A process leading to disease progression in Parkinson's disease. FASEB J 19: 533-542.

Zhou RM, Huang YX, Li XL, Chen C, Shi Q, Wang GR, Tian C, Wang ZY, Jing YY, Gao C, et al. 2010. Molecular interaction of $\alpha$-synuclein with tubulin influences on the polymerization of microtubule in vitro and structure of microtubule in cells. Mol Biol Rep 37: 3183-3192.

Zondler L, Miller-Fleming L, Repici M, Goncalves S, Tenreiro S, Rosado-Ramos R, Betzer C, Straatman KR, Jensen PH, Giorgini F, et al. 2014. DJ-1 interactions with $\alpha$ synuclein attenuate aggregation and cellular toxicity in models of Parkinson's disease. Cell Death Dis 5: e1350. 


\section{$\&_{\mathrm{CSH}}^{\infty} \&$ Cold Spring Harbor

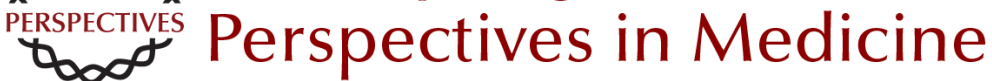

\section{Cell Biology and Pathophysiology of $\alpha$-Synuclein}

Jacqueline Burré, Manu Sharma and Thomas C. Südhof

Cold Spring Harb Perspect Med 2018; doi: 10.1101/cshperspect.a024091 originally published online January 20, 2017

\section{Subject Collection Prion Diseases}

TDP-43 Prions

Takashi Nonaka and Masato Hasegawa

$\alpha$-Synuclein: Multiple System Atrophy Prions

Amanda L. Woerman, Joel C. Watts, Atsushi

Aoyagi, et al.

Genetics of Synucleinopathies

Robert L. Nussbaum

$\beta$-Amyloid Prions and the Pathobiology of

Alzheimer's Disease

Joel C. Watts and Stanley B. Prusiner

Disease Mechanisms of C9ORF72 Repeat

Expansions

Tania F. Gendron and Leonard Petrucelli

Chronic Traumatic Encephalopathy: Is Latency in

Symptom Onset Explained by Tau Propagation? Joshua Kriegel, Zachary Papadopoulos and Ann C. McKee

Noncerebral Amyloidoses: Aspects on Seeding,

Cross-Seeding, and Transmission

Gunilla T. Westermark, Marcus Fändrich,

Katarzyna Lundmark, et al.

Structural and Chemical Biology of Presenilin

Complexes

Douglas S. Johnson, Yue-Ming Li, Martin

Pettersson, et al.
Cell Biology and Pathophysiology of $\alpha$-Synuclein Jacqueline Burré, Manu Sharma and Thomas C. Südhof

Molecular Mechanisms of Chronic Wasting

Disease Prion Propagation Julie A. Moreno and Glenn C. Telling

Genetics of Amyotrophic Lateral Sclerosis Mehdi Ghasemi and Robert H. Brown, Jr.

The Genetics of C9orf72 Expansions Ilse Gijselinck, Marc Cruts and Christine Van Broeckhoven

Prion-Like Characteristics of

Polyglutamine-Containing Proteins Margaret M.P. Pearce and Ron R. Kopito

Therapeutic Strategies for Restoring Tau Homeostasis

Zapporah T. Young, Sue Ann Mok and Jason E. Gestwicki

Fused in Sarcoma Neuropathology in Neurodegenerative Disease Ian R.A. Mackenzie and Manuela Neumann

Experimental Models of Inherited PrP Prion

Diseases

Joel C. Watts and Stanley B. Prusiner

For additional articles in this collection, see http://perspectivesinmedicine.cshlp.org/cgi/collection/ 